\title{
9. ANOXIC DIAGENESIS AND METHANE GENERATION IN SEDIMENTS OF THE BLAKE OUTER RIDGE, DEEP SEA DRILLING PROJECT SITE 533, LEG 76
}

\author{
George E. Claypool and Charles N. Threlkeld, U.S. Geological Survey, Denver, Colorado
}

\begin{abstract}
Concentrations and $\delta^{34} \mathrm{~S}$ and $\delta^{13} \mathrm{C}$ values were determined on $\mathrm{SO}_{4}^{2-}, \mathrm{HCO}_{3}^{-}, \mathrm{CO}_{2}$, and $\mathrm{CH}_{4}$ in interstitial water and gas samples from the uppermost $400 \mathrm{~m}$ of sediment on the Blake Outer Ridge. These measurements provide the basis for detailed interpretation of diagenetic processes associated with anaerobic respiration of electrons generated by organic-matter decomposition. The sediments are anaerobic at very shallow depths $(<1 \mathrm{~m})$ below the seafloor. Sulfate reduction is confined to the uppermost $15 \mathrm{~m}$ of sediment and results in a significant outflux of oxidized carbon from the sediments. At the base of the sulfate reduction zone, upward-diffusing $\mathrm{CH}_{4}$ is being oxidized, apparently in conjunction with $\mathrm{SO}_{4}^{2-}$ reduction. $\mathrm{CH}_{4}$ generation by $\mathrm{CO}_{2}$ reduction is the most important metabolic process below the $15-\mathrm{m}$ depth. $\mathrm{CO}_{2}$ removal is more rapid than $\mathrm{CO}_{2}$ input over the depth interval from 15 to $100 \mathrm{~m}$, and results in a slight decrease in $\mathrm{HCO}_{3}^{-}$concentration accompanied by a $40 \%$ positive shift in $\delta^{13} \mathrm{C}$. The differences among coexisting $\mathrm{CH}_{4}$, $\mathrm{CO}_{2}$, and $\mathrm{HCO}_{3}^{-}$are consistent with kinetic fractionation between $\mathrm{CH}_{4}$ and dissolved $\mathrm{CO}_{2}$, and equilibrium fractionation between $\mathrm{CO}_{2}$ and $\mathrm{HCO}_{3}^{-}$. At depths greater than $100 \mathrm{~m}$, the rate of input of $\mathrm{CO}_{2}\left(\delta^{13} \mathrm{C}=-25 \%\right.$ exceeds by 2 times the rate of removal of $\mathrm{CO}_{2}$ by conversion to $\mathrm{CH}_{4}\left(\delta^{13} \mathrm{C}\right.$ of -60 to $\left.-65 \%\right)$. This results in an increase of dissolved $\mathrm{HCO}_{3}^{-}$concentration while maintaining $\delta^{13} \mathrm{C}$ of $\mathrm{HCO}_{3}^{-}$relatively constant at $+10 \%$. Non-steady-state deposition has resulted in significantly higher organic carbon contents and unusually high $\left(70 \mathrm{meq} \mathrm{1}^{-1}\right)$ pore-water alkalinities below $150 \mathrm{~m}$. These high alkalinities are believed to be related more to spontaneous decarboxylation reactions than to biological processes. The general decrease in $\mathrm{HCO}_{3}^{-}$concentration with constant $\delta^{13} \mathrm{C}$ over the depth interval of 200 to $400 \mathrm{~m}$ probably reflects increased precipitation of authigenic carbonate.

Input-output carbon isotope-mass balance calculations, and carbonate system equilibria in conjunction with observed $\mathrm{CO}_{2}-\mathrm{CH}_{4}$ ratios in the gas phase, independently suggest that $\mathrm{CH}_{4}$ concentrations on the order of $100 \mathrm{mmol}$ $\mathrm{kg}^{-1}$ are present in the pore waters of Blake Outer Ridge sediments. This quantity of $\mathrm{CH}_{4}$ is believed to be insufficient to saturate pore waters and stabilize the $\mathrm{CH}_{4} \cdot 6 \mathrm{H}_{2} \mathrm{O}$ gas hydrate. Results of these calculations are in conflict with the physical recovery of gas hydrate from $238 \mathrm{~m}$, and with the indirect evidence (seismic reflectors, sediment frothing, slightly decreasing salinity and chlorinity with depth, and pressure core barrel observations) of gas-hydrate occurrence in these sediments. Resolution of this apparent conflict would be possible if $\mathrm{CH}_{4}$ generation were restricted to relatively thin (1-10 m) depth intervals, and did not occur uniformly at all depths throughout the sediment column, or if another methanogenic process (e.g., acetate fermentation) were a major contributor of gas.
\end{abstract}

\section{INTRODUCTION}

Leg 11 of the Deep Sea Drilling Project aroused awareness and interest in the occurrence of methane hydrate in deep-sea sediments (Stoll et al., 1971; Lancelot et al., 1971). High methane content is common in deepsea sediments deposited near continental margins (Claypool et al., 1973). Almost invariably the chemical and isotopic composition of the $\mathrm{CH}_{4}$ and $\mathrm{CO}_{2}$ coexisting in interstitial waters indicates that biological processes are responsible for the gas. Although many DSDP holes have penetrated gas-bearing sediments, and seismic evidence indicates that gas hydrates may be widespread (Tucholke et al., 1977; Shipley et al., 1979; Dillon et al., 1980), at only a few sites has the presence of gas hydrate been confirmed by physical recovery of hydrated sediment and measurement of decomposition volumes or pressures (Kvenvolden and Barnard, in press).

Site 533 of Leg 76 was essentially a re-drill of the Leg 11 gas-hydrate sites on the Blake Outer Ridge. The Blake Outer Ridge is a narrow southeastward extension of the continental rise about $640 \mathrm{~km}$ off the Atlantic coastline at the approximate latitude $\left(31^{\circ} 16^{\prime} \mathrm{N}, 74^{\circ}\right.$

\footnotetext{
${ }^{1}$ Sheridan, R. E., Gradstein, F. M., et al., Init. Repts. DSDP, 76: Washington (U.S. Govt. Printing Office).
}

$\left.52^{\prime} \mathrm{W}\right)$ of the Georgia-Florida state line. The water depth at Site 533 was $3284 \mathrm{~m}$, and the age of the $400 \mathrm{~m}$ of sediment cored was Quaternary and late Tertiary. The intention of Site 533 was to confirm the presence of gas hydrate by means of a specially designed pressure core barrel. The physical evidence for gas-hydrate occurrence is discussed elsewhere in this volume (Kvenvolden and Barnard). Our report focuses on the origin of the $\mathrm{CH}_{4}$ and, in particular, on the isotopic composition of dissolved carbonate species (mainly $\mathrm{HCO}_{3}^{-}$) in the interstitial water. Although organic matter is the ultimate source of most of the carbon that ends up as $\mathrm{CH}_{4}$, dissolved $\mathrm{CO}_{2}$ is the most important immediate $\mathrm{CH}_{4}$ precursor (Claypool and Kaplan, 1974), and this dissolved $\mathrm{CO}_{2}$ can be organic or inorganic in origin. Because of the large kinetic isotope effect (Rosenfeld and Silverman, 1959) associated with biological methanogenesis, the residual dissolved $\mathrm{CO}_{2}$ can become relatively enriched in ${ }^{13} \mathrm{C}$ shortly after the onset of methane generation. However, the interpretation of the $\delta^{13} \mathrm{C}$ of dissolved $\mathrm{CO}_{2}$ at a given depth in DSDP cores is complicated because many processes affect dissolved $\mathrm{CO}_{2}$ concentration and $\delta^{13} \mathrm{C}$. The main processes affecting dissolved $\mathrm{CO}_{2}$ are: biological (metabolic) $\mathrm{CO}_{2}$ production, thermal decarboxylation of organic matter, neutralization of organically derived $\mathrm{CO}_{2}$ by reaction with unsta- 
ble biogenic carbonates, biological reduction of $\mathrm{CO}_{2}$ to $\mathrm{CH}_{4}$, oxidation of upward diffusing $\mathrm{CH}_{4}$, and precipitation of authigenic carbonates. All these processes are occurring in the sediments of the Blake Outer Ridge. The differing relative rates of $\mathrm{SO}_{4}^{2-}$ consumption and $\mathrm{CO}_{2}$ production and consumption enables recognition of a depth sequence of diagenetic "zones" in marine sediments (Claypool and Kaplan, 1974). The general concept of major diagenetic zones has been used to reconstruct aspects of the postburial history of sediments containing carbonate concretions (Curtis, 1977; Irwin et al., 1977) and as a scheme for classification of sediments in terms of diagenetic environments (Berner, 1981). However, the quantitative interrelationship among sedimentation rates, rates of microbiological processes, and the time and spatial development of diagenetic zones remains to be worked out.

Blake Outer Ridge sediments provide one type of deep-sea depositional environment in which $\mathrm{SO}_{4}^{2-}$ reduction and $\mathrm{CH}_{4}$ generation can be studied. If the controlling factors for these processes can be isolated here and compared with similar factors in other anoxic environments, then perhaps the appropriate quantitative interrelationships can be developed for refined interpretation and prediction in a wide variety of depositional environments. An immediate objective in this line of research is to show how the environment of deposition controls the operation of subsequent diagenetic processes. Conversely, an ultimate objective is to show how the mineral products of early diagenesis preserved in ancient rocks can be used to reconstruct quantitative aspects of depositional environments.

An important product of the early diagenetic biological decomposition of organic matter is $\mathrm{CH}_{4}$, the principal component of natural gas. Natural gas of biogenic origin has become a worthwhile target for exploration (Rice and Claypool, 1981). Improved understanding of early diagenetic processes and their sedimentological effects likely will permit meaningful quantitative treatment of biological methanogenesis for purposes of exploration and resource appraisal, contrary opinions notwithstanding (Waples, 1981, p. 83).

\section{METHODS}

Sediment gas and interstitial water were sampled according to standard DSDP procedures (Gealy and Dubois, 1971; Manheim, 1966). Gas pockets visible through clear plastic core liners were tapped and gas was drawn off into an evacuated sampling tube (vacutainer). Water was squeezed from sediment with a hydraulic press, and collected, sealed, and stored under refrigeration in plastic syringes. Gases were analyzed by the procedure of Claypool et al. (1980), and water samples analyzed by the technique of Presley and Claypool (1971). $\mathrm{SO}_{4}^{2-}$ in water was determined by standard gravimetry (Presley, 1971); the resulting $\mathrm{BaSO}_{4}$ was converted to $\mathrm{SO}_{2}$ by quartz reduction (Holt and Engelkemeir, 1970). $\delta^{34} \mathrm{~S}$ and $\delta^{13} \mathrm{C}$ were measured by standard techniques (using double-collecting, $15-\mathrm{cm}$ radius, Nier-McKinney-type mass spectrometers) on $\mathrm{SO}_{2}$ and $\mathrm{CO}_{2}$ gas, and the results expressed in the delta notation $\left\{\delta, \%=\left[\left({ }^{\mathrm{R}}\right.\right.\right.$ sample $/{ }^{\mathrm{R}}$ standard $\left.)-1\right] 10^{3}$; where $\mathrm{R}=$ $\left.{ }^{34} \mathrm{~S} /{ }^{32} \mathrm{~S},{ }^{13} \mathrm{C} /{ }^{12} \mathrm{C}\right\}$ relative to Cañon Diablo trolite and PDB (Peedee belemnite) marine carbonate standards, respectively.

In the procedures described above, volumetric proportions of components of gas samples were determined by gas chromatography. $\mathrm{CH}_{4}$ and $\mathrm{CO}_{2}$ were collected quantitatively. $\mathrm{CH}_{4}$ was converted to $\mathrm{CO}_{2}$ by combustion and both the methane-derived and the original $\mathrm{CO}_{2}$ gas were purified and analyzed for $\delta^{13} \mathrm{C}$. Water samples of known weight were transferred to carbonate vacuum reaction flasks, frozen under nitrogen to prevent condensation of atmospheric $\mathrm{CO}_{2}$, pumped free of air, thawed, and acidified with $2 \mathrm{~N} \mathrm{HCl}$. The $\mathrm{CO}_{2}$ liberated from the interstitial water was purified, and the volume measured and $\delta^{13} \mathrm{C}$ determined. The acidified interstitial water was heated, and excess $\mathrm{BaCl}_{2}$ added to precipitate $\mathrm{BaSO}_{4}$, which was weighed and then converted to $\mathrm{SO}_{2}$ for $\delta^{34} \mathrm{~S}$ determination.

\section{RESULTS}

Pore-water samples from the two holes $(533,533 \mathrm{~A})$ analyzed in this study are listed by depth of burial in Table 1 . Concentration and $\delta^{34} \mathrm{~S}$ of dissolved $\mathrm{SO}_{4}^{2-}$ and concentration and $\delta^{13} \mathrm{C}$ of total dissolved carbonate $(\Sigma$ $\mathrm{CO}_{2}$ ) as determined in this study are reported, as well as the shipboard determinations of $\mathrm{pH}$ and titration alkalinity. $\mathrm{SO}_{4}^{2-}$ is present in significant amounts only in the three most shallow samples, at depths of less than $10 \mathrm{~m}$ beneath the seafloor. $\mathrm{SO}_{4}^{2-}$ concentration drops from assumed seawater values $\left(28 \mathrm{mmol} \mathrm{kg} \mathrm{kg}^{-1}\right)$ at the sediment/water interface to $20.4 \mathrm{mmol} \mathrm{kg}-1$ at a depth of $1.4 \mathrm{~m}$, to $16 \mathrm{mmol} \mathrm{kg}^{-1}$ at $3.5 \mathrm{~m}$, to $7 \mathrm{mmol} \mathrm{kg}^{-1}$ at 9.8 $\mathrm{m}$, and to essentially zero at some depth between 10 and $14.4 \mathrm{~m}$. The corresponding $\delta^{34} \mathrm{~S}$ values are $20 \%$ for seawater, $23.2 \%_{0}$ at $1.4 \mathrm{~m}, 28.5 \%$ at $3.5 \mathrm{~m}$, and $35.6 \%_{0}$ at $9.8 \mathrm{~m}$. $\mathrm{SO}_{4}^{2-}$ concentrations and $\delta^{34} \mathrm{~S}$ values are not measurable at depths below $10 \mathrm{~m}$.

The relationship of $\Sigma \mathrm{CO}_{2}$ and the $\delta^{13} \mathrm{C}$ of $\Sigma \mathrm{CO}_{2}$ with depth beneath the seafloor is shown in Figure 1. Dissolved $\Sigma \mathrm{CO}_{2}$ first increases in proportion to the $\mathrm{SO}_{4}^{2-}$ decrease, then decreases slightly before increasing again at greater depths. From seawater concentrations of about $2.5 \mathrm{mmol} \mathrm{kg}{ }^{-1}$ at the sediment/water interface, $\Sigma \mathrm{CO}_{2}$ increases regularly in four samples to about $19 \mathrm{mmol}$ $\mathrm{kg}^{-1}$ at a depth of $14.4 \mathrm{~m}$. $\Sigma \mathrm{CO}_{2}$ concentration decreases over the next seven samples to $14.4 \mathrm{mmol} \mathrm{kg}^{-1}$ at $93 \mathrm{~m}$, and then generally increases in the next seven samples to $32 \mathrm{mmol} \mathrm{kg}{ }^{-1}$ at $294 \mathrm{~m} . \Sigma \mathrm{CO}_{2}$ decreases over the next three samples to about $25 \mathrm{mmol} \mathrm{kg}^{-1}$ at a depth of about $400 \mathrm{~m}$. The $\delta^{13} \mathrm{C}$ of $\Sigma \mathrm{CO}_{2}$ roughly mirrors concentration over the depth interval of 0 to $100 \mathrm{~m}$, decreasing from $0 \%$ at the sediment/water interface to $-31 \%$ at $14 \mathrm{~m}$, then increasing to about $+5 \%$ at 100 $\mathrm{m}$. Below $100 \mathrm{~m}$ the $\delta^{13} \mathrm{C}$ of $\Sigma \mathrm{CO}_{2}$ continues to increase slowly to $+10 \%$ at about $200 \mathrm{~m}$, and then it decreases or remains relatively constant $(10 \pm 1 \%$ ) from 200 to $400 \mathrm{~m}$.

Figure 2 shows the shipboard alkalinity titrations plotted versus the measured pore-water $\Sigma \mathrm{CO}_{2}$ yields of this study. In general, $\Sigma \mathrm{CO}_{2}$ is only about $81 \%$ of the alkalinity, which should be $99 \%$ + due to dissolved carbonate species. Alkalinity, when calculated as $\mathrm{HCO}_{3}^{-}$, provides acceptable total cation-anion balance for the major ionic species in pore-water samples of Holes 533 and 533A (J. Geiskes, personal communication, 1982). Thus the alkalinity measurements probably provide a better estimate of the in situ $\mathrm{HCO}_{3}^{-}$concentrations than do the laboratory measurements of dissolved $\mathrm{\Sigma CO}_{2}$ in squeezed water samples. The main cause of the systematically low $\mathrm{CO}_{2}$ yields is believed to be loss of $\mathrm{CO}_{2}$ gas when the equilibrium represented by the equation

$$
2 \mathrm{HCO}_{3}^{-}=\mathrm{CO}_{2}+\mathrm{CO}_{3}^{2-}+\mathrm{H}_{2} \mathrm{O}
$$


Table 1. Concentration and stable isotope ratios of dissolved sulfate and total carbonate in interstitial waters, with $\mathrm{pH}$ and alkalinity, Blake Outer Ridge, DSDP Leg 76.

\begin{tabular}{|c|c|c|c|c|c|c|c|}
\hline \multirow[b]{2}{*}{$\begin{array}{c}\text { Sample } \\
\text { (hole-core-section) }\end{array}$} & \multirow{2}{*}{$\begin{array}{l}\text { Sub-bottom } \\
\text { depth } \\
\text { (m) }\end{array}$} & \multicolumn{2}{|l|}{$\mathrm{SO}_{4}^{2-}$} & \multicolumn{2}{|l|}{$\mathrm{\Sigma CO}_{2}$} & \multirow[b]{2}{*}{$\mathrm{pH}^{\mathrm{a}}$} & \multirow{2}{*}{$\begin{array}{c}\text { Titration } \\
\text { alkalinity } \\
\left(\mathrm{mmol} \mathrm{kg}^{-1}\right)\end{array}$} \\
\hline & & $\left(\mathrm{mmol} \mathrm{kg}^{-1}\right)$ & $\begin{array}{l}\delta^{344} S \\
(\%)\end{array}$ & $\left(\mathrm{mmol} \mathrm{kg}^{-1}\right)$ & $\begin{array}{l}{ }^{\delta^{13} \mathrm{C}} \\
(\%)\end{array}$ & & \\
\hline $533-1-1$ & 1.4 & 20.4 & 23.2 & 5.4 & -17.4 & 7.4 & 8.3 \\
\hline $533-2-1$ & 3.5 & 16 & 28.5 & 7.6 & -19.0 & 7.6 & 11.5 \\
\hline $533-5-1$ & 9.8 & 7 & 35.6 & 11.7 & -27.4 & 7.5 & 18.0 \\
\hline $533-6-2$ & 14.4 & $<0.1$ & - & 18.6 & -31.4 & 7.6 & 23.9 \\
\hline $533-8-1$ & 21.8 & $-^{b}$ & - & 18.3 & -24.6 & 7.7 & 25.7 \\
\hline $533-10-2$ & 32.3 & $<0.1$ & - & 18.0 & -13.7 & 8.1 & 24.9 \\
\hline $533-12-1$ & 39.8 & $<0.1$ & - & 17.7 & -8.8 & 7.6 & 24.3 \\
\hline $533-14-1$ & 48.5 & $<0.1$ & - & 16.1 & -6.4 & 7.9 & 23.9 \\
\hline $533-20-2$ & 76 & - & - & 15.8 & 1.2 & 7.8 & 24.1 \\
\hline $533-22-1$ & 84 & 0.3 & - & 14.6 & 2.5 & 7.8 & 22.8 \\
\hline $533-24-1$ & 93 & - & - & 14.4 & 3.7 & 7.8 & 23.0 \\
\hline $533-28-2$ & 112 & 0.1 & - & 16.0 & 5.5 & 7.9 & 22.5 \\
\hline $533-34-1$ & 137 & $<0.1$ & - & 17.7 & 6.9 & 7.9 & 26.4 \\
\hline $533 \mathrm{~A}-4-2$ & 158 & 1.1 & - & 8.9 & 8.7 & 7.6 & 34.2 \\
\hline $533-40-1$ & 160 & $<0.1$ & - & 21.2 & 7.9 & 7.9 & 31.9 \\
\hline $533-8-2$ & 193 & 0.3 & - & 30.7 & 10.4 & 7.4 & 66.6 \\
\hline $533-15-1$ & 258 & - & - & 26.7 & 10.8 & 7.6 & 39.6 \\
\hline $533-18-6$ & 294 & 0.3 & - & 31.9 & 10.7 & 7.5 & 46.8 \\
\hline $533-22-6$ & 332 & - & - & 28.5 & 10.1 & 7.6 & 41.2 \\
\hline $533-26-3$ & 365 & - & - & 24.9 & 9.9 & 7.5 & 47.7 \\
\hline $533-29-3$ & 396 & - & - & 24.8 & 9.9 & 7.2 & 39.8 \\
\hline
\end{tabular}

a Shipboard measurements; alkalinity measured in meq $\mathrm{I}^{-1}$ and converted to mmol kg ${ }^{-1}$ by dividing by 1.03 $\mathrm{kg} \mathrm{l}^{-1}$.

$\mathrm{b}-=$ no analysis.

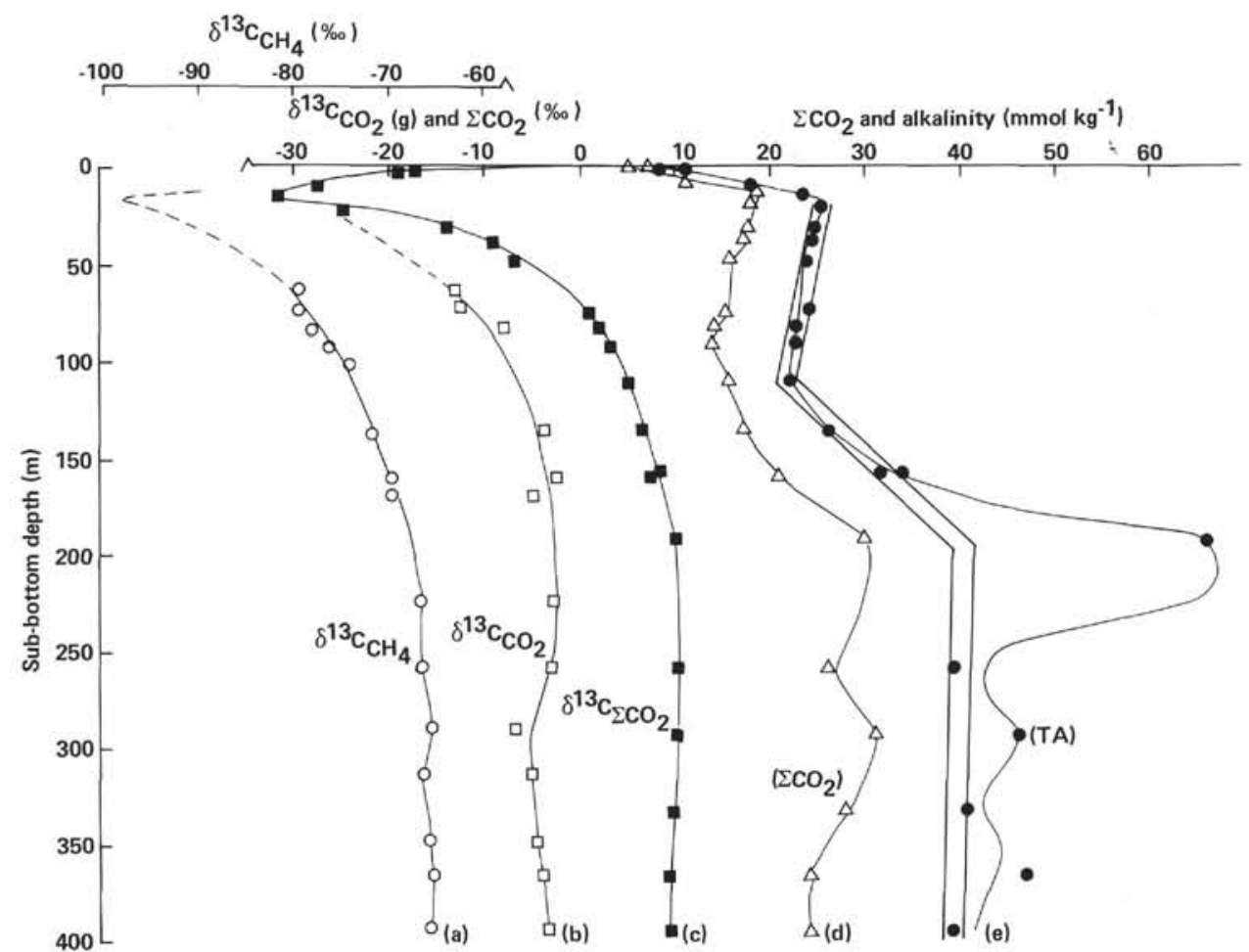

Figure 1. $\delta^{13} \mathrm{C}$ values of $\mathrm{CH}_{4}$ (curve a) and $\mathrm{CO}_{2}$ (curve b) in gas (g) samples, and of $\Sigma \mathrm{CO}_{2}$ (curve c) in interstitial water samples, and $\mathrm{\Sigma CO}_{2}$ concentration (curve d) and (shipboard) titration alkalinity (TA) (curve e) as a function of sub-bottom burial depth in sediments of DSDP Holes 533 and 533A. (Double solid lines on alkalinity curve represent $\mathrm{HCO}_{3}^{-}$concentration-depth trend for purpose of input-output carbon isotope and carbon mass balance calculations.

is shifted to the right by pressure changes associated with core retrieval and squeezing. This systematic difference was not noted in samples from gassy sediments cored on earlier legs of DSDP (e.g., Leg 15, Hammond, 1973; Leg 18, Claypool, unpublished data) and may be due to some change in sampling procedures.
The chemical composition of gas samples is reported in Table 2. The main components are $\mathrm{CH}_{4}, \mathrm{CO}_{2}$, and $\mathrm{C}_{2} \mathrm{H}_{6}$, plus variable amounts of "air" or $\mathrm{N}_{2}$ analyzed as an undifferentiated chromatographic peak. On an "air"free basis, the relative contents of both $\mathrm{CO}_{2}$ and $\mathrm{C}_{2} \mathrm{H}_{6}$ generally increase with increasing depth of burial. When 


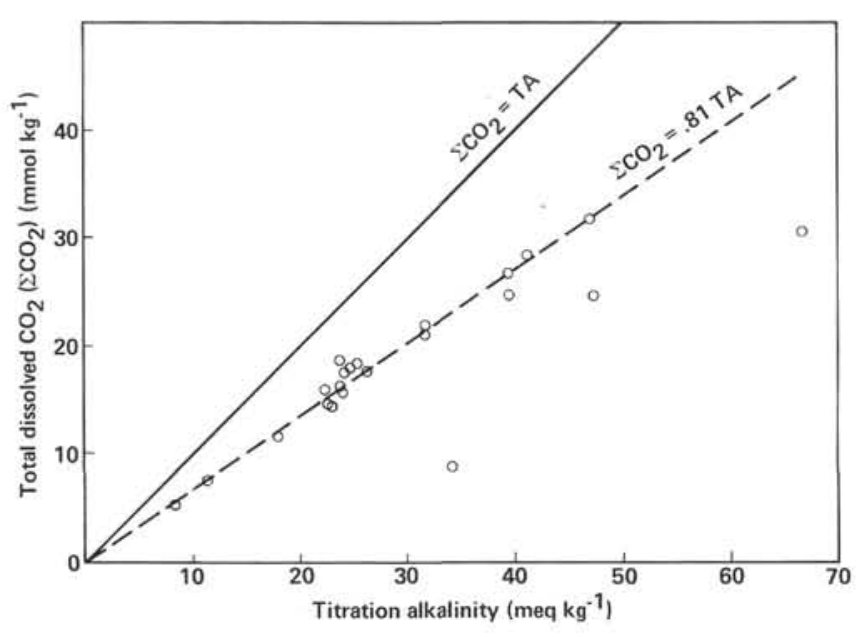

Figure 2. Shipboard titration alkalinity (TA) versus laboratory measurement of total dissolved $\mathrm{CO}_{2}$ in aliquots of interstitial water samples from Holes 533 and 533A. (Solid line indicates theoretical relationship if alkalinity is mainly due to dissolved $\mathrm{HCO}_{3}^{-}$and if there is no loss of dissolved $\mathrm{CO}_{2}$ during sampling. Dashed line shows that experimental points cluster about the relationship in which total dissolved $\mathrm{CO}_{2}$ equals 0.81 titration alkalinity.)

normalized by $\mathrm{CH}_{4}$ content, the $\mathrm{CO}_{2}-\mathrm{CH}_{4}$ ratio initially drops over the depth interval above $100 \mathrm{~m}$, and then increases between 100 and $400 \mathrm{~m} . \mathrm{C}_{2} \mathrm{H}_{6}-\mathrm{CH}_{4}$ ratio increases exponentially with increasing depth of burial, as is typical for DSDP sediments. $\mathrm{C}_{2} \mathrm{H}_{6}$ content in gas of predominantly biogenic origin usually reflects both the original concentration and degree of conversion of $\mathrm{C}_{2} \mathrm{H}_{6}$ precursors (proportional to total organic matter content and temperature history). Therefore, the relatively steep slope of the exponential $\mathrm{C}_{2} \mathrm{H}_{6}-\mathrm{CH}_{4}$ gradient reflects the slightly higher than normal thermal gradient $\left(36^{\circ} \mathrm{C}\right.$ $\mathrm{km}^{-1}$ ) and above-average (for continental margin deepsea sediments) organic carbon contents (1-1.5\% at depths $>150 \mathrm{~m}$ ).

$\delta^{13} \mathrm{C}$ values of $\mathrm{CH}_{4}$ and $\mathrm{CO}_{2}$ gas are also shown in Figure 1. The shallowest gas sample analyzed in this study $(64 \mathrm{~m})$ contained the isotopically lightest $\mathrm{CH}_{4}$ and
$\mathrm{CO}_{2}, \delta^{13} \mathrm{C}$ of $-81.3 \%$ and $-11.9 \%$, respectively. The $\delta^{13} \mathrm{C}$ values for $\mathrm{CH}_{4}$ increase regularly with depth, reaching a value of about $-68 \%$ at $224 \mathrm{~m}$. Below $200 \mathrm{~m}$ the $\delta^{13} \mathrm{C}$ of $\mathrm{CH}_{4}$ is relatively constant $(-67.7 \pm 0.5 \%$ ). Dissolved $\Sigma \mathrm{CO}_{2}$ roughly parallels $\mathrm{CH}_{4}$ in $\delta^{13} \mathrm{C}$, but the difference $\left(\Delta^{13}\left[\Sigma \mathrm{CO}_{2}-\mathrm{CH}_{4}\right]\right)$ estimated from samples from the same depth in Tables 1 and 2 decreases regularly from about 82 to $78 \%$. The observed $\Delta^{13}\left[\Sigma \mathrm{CO}_{2}-\right.$ $\left.\mathrm{CO}_{2}(\mathrm{~g})\right]$ difference is more variable, but for 7 of 8 samples falls in the range of 10 to $14 \%$.

\section{DISCUSSION}

The amounts and stable isotope ratios of $\mathrm{SO}_{4}^{2-}$, $\mathrm{HCO}_{3}^{-}$, and $\mathrm{CH}_{4}$ in the interstitial fluids of Blake Outer Ridge sediments at Site 533 reflect the biological activity of microorganisms operating in the sediments beneath the seafloor to depths of at least $200 \mathrm{~m}$, and probably deeper. (In the following discussion, total dissolved $\mathrm{CO}_{2}$ is usually referred to as $\mathrm{HCO}_{3}^{-}$because that is the predominant species under in situ conditions). Dissolved oxygen apparently is absent from the interstitial water at a very shallow $(<1 \mathrm{~m})$ depth, because the shallowest pore-water sample (at $1.4 \mathrm{~m}$ ) shows evidence of extensive sulfate reduction. Dissolved $\mathrm{SO}_{4}^{2-}$ itself is absent below about $15 \mathrm{~m}$, so the main process of anaerobic respiration that permits continued metabolic activity at greater depths in Blake Outer Ridge sediments is $\mathrm{CO}_{2}$ reduction to yield $\mathrm{CH}_{4}$. Dissolved $\mathrm{CO}_{2}$ is not depleted in these sediments because of continued $\mathrm{CO}_{2}$ replenishment at depth by "fermentation" and by nonbiological (time-temperature controlled) decarboxylation reactions.

\section{Quantitative Interpretation}

In the discussion that follows, equations describing changes in concentration and stable isotope ratios of dissolved $\mathrm{SO}_{4}^{2-}$ and $\mathrm{HCO}_{3}^{-}$are applied to interstitial fluid data from Site 533. These mathematical treatments are variations of the Rayleigh distillation, and they describe the isotope ratio of the residual reactant $\left(\mathrm{SO}_{4}^{2-}\right.$ or $\mathrm{HCO}_{3}^{-}$) as a function of reaction progress. In both $\mathrm{SO}_{4}^{2-}$ reduction and $\mathrm{CO}_{2}$ reduction, the classical Rayleigh

Table 2. Composition of vacutainer gas samples from gas pockets in cores and carbon isotope ratios of gaseous $\mathrm{CO}_{2}$ and $\mathrm{CH}_{4}$, Blake Outer Ridge, DSDP Leg 76.

\begin{tabular}{|c|c|c|c|c|c|c|c|}
\hline \multirow[b]{2}{*}{$\begin{array}{c}\text { Sample } \\
\text { (hole-core-section) }\end{array}$} & \multirow{2}{*}{$\begin{array}{l}\text { Sub-bottom } \\
\text { depth } \\
\text { (m) }\end{array}$} & \multicolumn{2}{|c|}{ Major components } & \multicolumn{2}{|c|}{$\begin{array}{c}\text { Minor components, } \\
\text { volume ratios }\end{array}$} & \multicolumn{2}{|c|}{$\begin{array}{c}{ }^{{ }^{13}} \mathrm{C}(\%) \\
\text { versus PDB }\end{array}$} \\
\hline & & $\begin{array}{l}\mathrm{N}_{2}-" \text { "air" } \\
\text { (vol. \%) }\end{array}$ & $\underset{\text { (vol. \%) }}{\mathrm{CH}_{4}}$ & $\mathrm{CO}_{2}-\mathrm{CH}_{4}$ & $\left(C_{2}-C_{1}\right) 10^{4^{a}}$ & $\mathrm{CH}_{4}$ & $\mathrm{CO}_{2}$ \\
\hline $533 \mathrm{~A}-1-6$ & 64 & 21.02 & 77.76 & 0.015 & 0.28 & -81.3 & -11.9 \\
\hline $533-20-1$ & 74 & 28.24 & 70.81 & 0.013 & 0.21 & -81.3 & -11.1 \\
\hline $533-22-1$ & 84 & 25.17 & 73.70 & 0.015 & 0.15 & -79.8 & -87 \\
\hline $533-24-2$ & 93 & 22.48 & 77.36 & 0.002 & 0.16 & -78.0 & $-b$ \\
\hline $533-28-3$ & 113 & 29.13 & 70.04 & 0.012 & 0.26 & -75.9 & - \\
\hline $533-34-1$ & 137 & 25.81 & 72.28 & 0.025 & 0.23 & -73.5 & -3.5 \\
\hline $533-40-2$ & 161 & 27.23 & 69.97 & 0.040 & 0.25 & -71.3 & -2.0 \\
\hline $533 \mathrm{~A}-5-6$ & 170 & 27.59 & 71.53 & 0.012 & 0.21 & -71.3 & -4.5 \\
\hline $533 \mathrm{~A}-11-4$ & 224 & 41.46 & 55.89 & 0.047 & 0.56 & -68.2 & -2.6 \\
\hline $533 \mathrm{~A}-15-2$ & 259 & 27.86 & 69.89 & 0.032 & 0.59 & -68.1 & -2.9 \\
\hline $533 \mathrm{~A}-18-4$ & 290 & 26.87 & 71.84 & 0.018 & 1.24 & -67.1 & -6.3 \\
\hline $533 \mathrm{~A}-20-6$ & 313 & 30.82 & 66.41 & 0.041 & 1.56 & -68.1 & -4.8 \\
\hline $533 \mathrm{~A}-24-5$ & 348 & 25.32 & 70.46 & 0.060 & 0.91 & -67.5 & -4.3 \\
\hline $533 \mathrm{~A}-26-4$ & 366 & 42.95 & 52.85 & 0.079 & 2.56 & -67.2 & -3.8 \\
\hline $533 \mathrm{~A}-29-1$ & 393 & 22.28 & 71.46 & 0.088 & 2.38 & -67.6 & -2.9 \\
\hline
\end{tabular}

a Shipboard measurement.

b $-=$ no analysis. 
distillation treatment of a fixed initial reactant reservoir has been modified to allow for addition of reactant during the reaction process. The notation and terminology of the original sources for these mathematical treatments (Claypool, 1974; Wigley et al., 1978) have been retained in order to avoid detailed description in the present report, even though some different conventions are used for similar processes as a result.

The objectives of the quantitative treatment are somewhat different for the two major processes discussed. For $\mathrm{SO}_{4}^{2-}$ reduction, the emphasis is on evaluating the magnitude of exchange of dissolved ionic constituents between shallow sediments and overlying seawater. In addition, the carbon-sulfur stoichiometry for $\mathrm{SO}_{4}^{2-}$ reduction is examined to evaluate the possibility of apparently anaerobic $\mathrm{CH}_{4}$ oxidation. For $\mathrm{CO}_{2}$ reduction, the emphasis is placed on estimating the amount of methane produced.

\section{Sulfate Reduction Zone (0-15 m)}

Gradients in both concentration and $\delta^{34} \mathrm{~S}$ of dissolved sulfate are apparent in the three most shallow samples from Hole $533(1.4 \mathrm{~m}, 3.5 \mathrm{~m}$, and $9.8 \mathrm{~m})$. The number of samples is insuffient to determine the exact shape of the curves, but if we make some allowance for possible uncertainties in the measurements, the data are not inconsistent with an exponential decrease in $\mathrm{SO}_{4}^{2-}$, as plotted in Figure 3. The terms $\ln C / C_{0}$ and $\ln R / \mathrm{R}_{0}$ refer to the natural $\log$ of the normalized concentration and ${ }^{34} \mathrm{~S} /$ ${ }^{32} \mathrm{~S}$ values, where $\mathrm{C}_{0}=28 \mathrm{mmol} \mathrm{kg}{ }^{-1}$ and $\mathrm{R} / \mathrm{R}_{0}=(\delta$ $+1000) /\left(\delta_{0}+1000\right)$, with $\delta_{0}=20 \%$. If $\mathrm{SO}_{4}^{2-}$ reduction is essentially unidirectional and the light and heavy isotopes of $\mathrm{SO}_{4}^{2-}$ react at different rates as symbolized by

$$
\begin{aligned}
& { }^{32} \mathrm{SO}_{4}^{2-}-{ }^{32} \mathrm{k}^{32} \mathrm{~S}^{2-} \\
& { }^{34} \mathrm{SO}_{4}^{2-}{ }^{34} \mathrm{k}^{34} \mathrm{~S}^{2-}
\end{aligned}
$$

then the ratio of the slopes of the lines in Figure 3 give an apparent rate constant ratio $\left[\left({ }^{32} \mathrm{k} /{ }^{34} \mathrm{k}\right)=\alpha\right]$ for $\mathrm{SO}_{4}^{2-}$ reduction of 1.012, where $\alpha$ comes from a form of the Rayleigh equation

$$
\left(\Delta \ln \mathrm{R} / \mathrm{R}_{0}\right) /\left(-\Delta \ln \mathrm{C} / \mathrm{C}_{0}\right)=1-(1 / \alpha),
$$

and where $\Delta$ indicates slope of the lines in Figure 2 (Claypool, 1974). The deviation of the apparent fractionation factor $\left(\alpha_{\mathrm{a}}\right)$ from the "true" closed-system $\alpha$, which is believed to approach the theoretical equilibrium value of 1.074 at $25^{\circ} \mathrm{C}$ (Tudge and Thode, 1951; Sakai, 1957) is a measure of the amount of $\mathrm{SO}_{4}^{2-}$ that diffused into the sediments from the overlying seawater. A semiquantitative treatment of marine pore water $\mathrm{SO}_{4}^{2-}$ (Claypool, 1974) considers the process of $\mathrm{SO}_{4}^{2-}$ reduction as occurring between two end-member examples-complete "closed system" and complete "open system." Complete "closed system" refers to $\mathrm{SO}_{4}^{2-}$ reduction without replenishment by diffusion from overlying seawater. Complete "open system" refers to sulfate reduction with replenishment by diffusion in such a manner that there

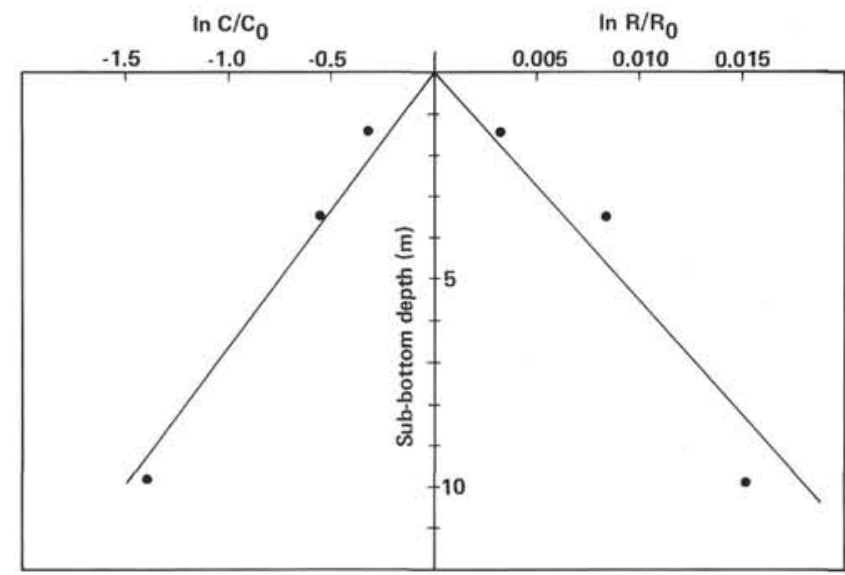

Figure 3. Logarithmic plot of normalized concentration and sulfur isotope ratio versus depth for sulfate dissolved in the interstitial water of Hole 533 ( $\ln C / C_{0}$ and $\ln R / R_{0}$ refer to the natural logarithm of the sulfate concentration $[\mathrm{C}]$ or ${ }^{34} \mathrm{~S} /{ }^{32} \mathrm{~S}[\mathrm{R}]$ divided by the corresponding initial or seawater sulfate values $\left.\left[\mathrm{C}_{0}, \mathrm{R}_{0}\right]\right)$.

is no $\mathrm{SO}_{4}^{2-}$ depletion and no ${ }^{34} \mathrm{~S}$ enrichment in the pore water, even though coexisting sulfide species may be strongly depleted in ${ }^{34} \mathrm{~S}$. In the complete "closed-system" example, the apparent fractionation factor obtained from the Raleigh equation is the same as the "true" fractionation factor (i.e., $\alpha_{\mathrm{a}}=\alpha=1.075$ ). In the "open-system" example, isotopic fractionation is not reflected in the pore-water sulfate (i.e., $\alpha_{\mathrm{a}}=1.000$ ). For intermediate examples, the apparent fractionation factor is related to the relative proportions of $\mathrm{SO}_{4}^{2-}$ supplied by diffusion and burial by the equation

$$
\frac{\text { diffusion flux }}{\text { burial flux }}=\frac{1.075-\alpha_{a}}{\alpha_{a}-1}
$$

where flux is in mass per unit area per unit time. The $\mathrm{SO}_{4}^{2-}$ concentration and $\delta^{34} \mathrm{~S}$ gradients in Hole 533 give $\alpha_{\mathrm{a}}=1.012$ from the Raleigh equation. From the equation above, this value of $\alpha_{\mathrm{a}}$ implies that the diffusion flux is 5.25 times the burial flux.

The flux relationship implies a relatively large exchange of dissolved material between seawater and the sediments of the Blake Outer Ridge. In order to maintain charge balance, the influx of $\mathrm{SO}_{4}^{2-}$ must be accompanied by an influx of cations $\left(\mathrm{Mg}^{2+}, \mathrm{Ca}^{2+}\right)$ or an outflux of anions. Flux of dissolved $\mathrm{HCO}_{3}^{-}$out of Blake Outer Ridge sediments probably compensates for the bulk of $\mathrm{SO}_{4}^{2-}$ influx. The burial flux of $\mathrm{SO}_{4}^{2-}$ is given approximately by the product of sedimentation rate times porosity times $\mathrm{SO}_{4}^{2-}$ concentration, or about 2 $\mathrm{mmol} \mathrm{m}-2 \mathrm{yr}^{-1}$. If $\mathrm{SO}_{4}^{2-}$ diffusion influx is balanced by $\mathrm{HCO}_{3}^{-}$outflux, the implication is that about $20 \mathrm{mmol}$ $\mathrm{m}^{-2} \mathrm{yr} .^{-1}$ of $\mathrm{HCO}_{3}^{-}$is pumped out of the sediments into overlying seawater in the region of the Blake Outer Ridge.

The relationship between dissolved $\mathrm{SO}_{4}^{2-}$ and (1) dissolved $\Sigma \mathrm{CO}_{2}$, (2) titration alkalinity, and (3) the theoretical amount of $\mathrm{HCO}_{3}^{-}$generated by the reaction

$$
2 \mathrm{CH}_{2} \mathrm{O}+\mathrm{SO}_{4}^{2-} \rightarrow 2 \mathrm{HCO}_{3}^{-}+\mathrm{H}_{2} \mathrm{~S}
$$


is shown in Figure 4. The observed amount of $\mathrm{HCO}_{3}^{-}$at any given depth is deficient compared with the amount expected from the degree of $\mathrm{SO}_{4}^{2-}$ depletion, if it is assumed that $\mathrm{SO}_{4}^{2-}$ reduction is coupled with decomposition of organic matter having the oxidation state of carbohydrate, represented by the formula $\mathrm{CH}_{2} \mathrm{O}$. As discussed earlier, the alkalinity provides the best available estimate of in situ $\mathrm{HCO}_{3}^{-}$concentration; even so, the apparent stoichiometric relationship between $\mathrm{SO}_{4}^{2-}$ and $\mathrm{HCO}_{3}^{-}$is less than half that predicted by the reaction just described.

There are three possible reasons for this apparent $\mathrm{HCO}_{3}^{-}$deficiency. First $\mathrm{HCO}_{3}^{-}$concentration could be depleted due to precipitation of authigenic carbonate. Second, $\mathrm{HCO}_{3}^{-}$concentration in the zone of $\mathrm{SO}_{4}^{2-}$ reduction could be depleted by diffusion. And third, an appreciable amount of $\mathrm{SO}_{4}^{2-}$ reduction could be coupled (directly or indirectly) with the decomposition of organic matter with a lower oxidation state than carbohydrate $\left(\mathrm{CH}_{2} \mathrm{O}\right)$. Evidence can be presented to support the influence of each of these processes on the observed $\mathrm{HCO}_{3}^{-}$ concentration in the zone of $\mathrm{SO}_{4}^{2-}$ reduction.

The combined $\mathrm{Ca}^{2+}$ and $\mathrm{Mg}^{2+}$ decrease in the interval from 0 to $15 \mathrm{~m}$ at Site 533 of about $20 \mathrm{mmol} \mathrm{kg}^{-1}$ is undoubtedly associated with precipitation of some carbonate. Lawrence (1973) discussed authigenic carbonate

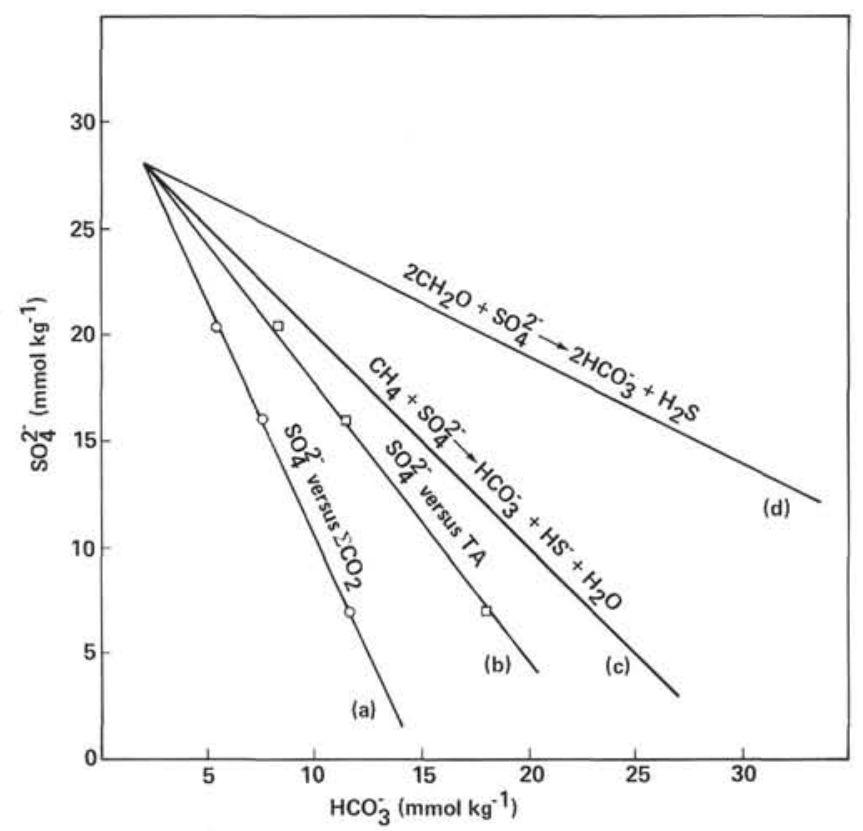

Figure 4. Plot of $\mathrm{SO}_{4}^{2-}$ concentration versus estimate of $\mathrm{HCO}_{3}^{-}$concentration, and observed versus theoretical sulfur-carbon stoichiometry for sulfate reduction and apparent bicarbonate deficiency in shallow sediments $(<10 \mathrm{~m}$ sub-bottom) of Hole 533. (Straight lines are given by the equation $\mathrm{HCO}_{3}^{-}=1 \mathrm{mmol}+[28-\mathrm{S}$ / $\mathrm{C}\left(\mathrm{SO}_{4}^{2-}\right)$ ], where $\mathrm{S} / \mathrm{C}$ is the molar ratio of sulfur consumed to carbon produced during sulfate reduction. Observed $\mathrm{S} / \mathrm{C}$ values are 0.46 [line a] or 0.77 [line b], depending on whether $\mathrm{HCO}_{3}^{-}$concentration is taken as total dissolved $\mathrm{CO}_{2}\left[\Sigma \mathrm{LO}_{2}\right]$ or titration alkalinity [TA], respectively. Lines $\mathrm{c}$ and $\mathrm{d}$ illustrate theoretical sulfur-carbon stoichiometry for sulfate reduction using methane $[\mathrm{S} / \mathrm{C}=1]$ and carbohydrate $[\mathrm{S} / \mathrm{C}=2]$, respectively, as an energy source.) precipitation in the zone of $\mathrm{SO}_{4}^{2-}$ reduction at Site 148 and found $\delta^{13} \mathrm{C}$ values for carbonate in bulk sediment that supports such a process.

Upward diffusion of $\mathrm{HCO}_{3}^{-}$to seawater must occur, but this process could not account for the $\mathrm{HCO}_{3}^{-}$deficiency, if it is coupled with influx of $\mathrm{SO}_{4}^{2-}$ that produces additional $\mathrm{HCO}_{3}^{-}$upon reduction. Downward diffusion of $\mathrm{HCO}_{3}^{-}$into the zone of $\mathrm{CH}_{4}$ generation is more likely, but would have to be coupled with downward diffusion of cations to maintain charge balance. The gradients of $\mathrm{HCO}_{3}^{-}$and $\mathrm{Mg}^{2}+$ below the zone of sulfate reduction $(0-15 \mathrm{~m})$ indicate that such diffusion would be possible but may not be a major process.

There is good evidence that $\mathrm{CH}_{4}$ is being oxidized within the zone of sulfate reduction. The $\delta^{13} \mathrm{C}$ of $\Sigma \mathrm{CO}_{2}$ in pore-water samples from 9.8 and $14.4 \mathrm{~m}$ are too light $\left(\delta^{13} \mathrm{C}\right.$ of -27.4 and $-31.4 \%$, respectively) to be derived from anaerobic oxidation of normal marine organic matter. In addition, small concentrations of isotopically heavy $\mathrm{CH}_{4}\left(\delta^{13} \mathrm{C}\right.$ of $-42 \%$ ) occur within the zone of sulfate reduction at a depth of about $10 \mathrm{~m}$ (Brooks et al., this volume). Both of these isotopic anomalies could be explained by upward diffusion and oxidation of $\mathrm{CH}_{4}$ within the zone of sulfate reduction. $\mathrm{CH}_{4}$ with $\delta^{13} \mathrm{C}$ approaching $-100 \%$ is observed at depths of about $20 \mathrm{~m}$ (Brooks et al., this volume). Upward diffusion and oxidation of relatively small amounts of such $\mathrm{CH}_{4}$ would have a major impact on the $\delta^{13} \mathrm{C}$ of dissolved $\mathrm{HCO}_{3}^{-}$. Several studies have shown that ${ }^{12} \mathrm{CH}_{4}$ is preferentially oxidized, leaving the residual methane enriched in ${ }^{13} \mathrm{C}$ (Coleman et al., 1981; Lebedev et al., 1969). The simplest explanation for $\mathrm{HCO}_{3}^{-}$deficiency in the zone of $\mathrm{SO}_{4}^{2-}$ reduction at Site 533 is anaerobic oxidation of $\mathrm{CH}_{4}$ coupled with sulfate reduction, as in the reaction

$$
\mathrm{CH}_{4}+\mathrm{SO}_{4}^{2-} \rightarrow \mathrm{HCO}_{3}^{-}+\mathrm{HS}^{-}+\mathrm{H}_{2} \mathrm{O} \text {. }
$$

In this reaction, $\mathrm{HCO}_{3}^{-}: \mathrm{SO}_{4}^{2-}$ stoichiometry is $1: 1 \mathrm{in}$ stead of $2: 1$, as in the oxidation of $\mathrm{CH}_{2} \mathrm{O}$. That this reaction can take place as written is not universally accepted (Postgate, 1965; Sorokin, 1957). Although the exact mechanism may be in doubt, there seems to be little question that $\mathrm{CH}_{4}$ is being oxidized in the zone of sulfate reduction. Alternative explanations to $\mathrm{CH}_{4}$ oxidation directly coupled with $\mathrm{SO}_{4}^{2-}$ reduction are necessarily more complex.

Microaerophylic methane-oxidizing bacteria may be nearly symbiotic with sulfate-reducing bacteria (Cappenberg, 1972, Jannasch, 1975). $\mathrm{CH}_{4}$ oxidation could take place in oxic microenvironments within the generally anoxic $\mathrm{SO}_{4}^{2-}$ reducing zone. For purposes of interpreting processes occurring in the Blake Outer Ridge sediments, it is probably best to adopt the simplest explanation $\left(\mathrm{CH}_{4}\right.$ oxidation directly coupled with $\mathrm{SO}_{4}$ reduction) while realizing that the details of the actual process probably are more complicated.

\section{Carbonate Reduction Zone (15-400 m)}

Below a depth of about $15 \mathrm{~m}$ sub-bottom in Hole 533 , the trend of increase in dissolved $\Sigma \mathrm{CO}_{2}$ concentration reverses and begins to decrease, and the trend of de- 
crease in $\delta^{13} \mathrm{C}$ of dissolved $\Sigma \mathrm{CO}_{2}$ reverses and begins to increase (Fig. 1). This depth $(\simeq 15 \mathrm{~m})$ marks the transition between the zones of active $\mathrm{SO}_{4}^{2-}$ reduction above and carbonate reduction-methanogenesis below. $\mathrm{Al}$ though small amounts of partially oxidized residual $\mathrm{CH}_{4}$ are present at depths shallower than $15 \mathrm{~m}$ (Brooks et al., this volume), this $\mathrm{CH}_{4}$ likely is (1) diffusing up from the deeper zone of active methanogenesis or (2) produced in $\mathrm{SO}_{4}^{2-}$-free microenvironments or (3) produced at slow rates in conjunction with $\mathrm{SO}_{4}^{2-}$ reduction, or some combination of these. At any rate, the dominant processes of anaerobic respiration are effectively separated, if not mutually exclusive in the strictest sense.

The main objectives of the present study of pore fluids in Blake Outer.Ridge sediments are (1) to evaluate the amount of $\mathrm{CH}_{4}$ produced during early diagenesis, and (2) to clarify the factors controlling the chemical and the isotopic composition of authigenic carbonates formed during early diagenesis. The carbon reservoir from which both $\mathrm{CH}_{4}$ and authigenic carbonate are directly formed is the total dissolved carbonate in the pore water, which is present mainly as $\mathrm{HCO}_{3}^{-}$. However, the carbon transferred through the dissolved $\mathrm{HCO}_{3}^{-}$reservoir ultimately is derived from unstable carbonaceouscalcareous solid substances, that is, organic matter, aragonite, and high-Mg calcite. In this study we determine the changes in the concentration and $\delta^{13} \mathrm{C}$ of dissolved $\mathrm{HCO}_{3}^{-}$as a function of depth of burial or time and relate these changes, in as quantitative a fashion as is justified by our present understanding, to the diagenetic processes of principal interest. This approach is analogous to investigating the process of sulfate reduction by determining concentration and $\delta^{34} \mathrm{~S}$ of residual dissolved sulfate. However, unlike the case of dissolved $\mathrm{SO}_{4}^{2-}$ in marine sediments, which is buried at fixed concentration and is only replenished by diffusion from overlying seawater, the dissolved $\mathrm{HCO}_{3}^{-}$reservoir has more potential inputs and outputs. This greatly complicates the interpretation of $\mathrm{HCO}_{3}^{-}$concentration and $\delta^{13} \mathrm{C}$ in the pore waters of marine sediments.

Considering interstitial water $\mathrm{SO}_{4}^{2-}$, there are two inputs (burial, diffusion) and one output $\left(\mathrm{SO}_{4}^{2-}\right.$ reduction). For total $\mathrm{CO}_{2}$ dissolved in pore waters there are three inputs (burial, organic-matter decomposition, and carbonate dissolution) and three outputs (diffusion, carbonate reduction-methanogenesis, and carbonate precipitation). For purposes of initial interpretation of Hole 533 data, the burial and carbonate dissolution inputs and the diffusion output of $\mathrm{HCO}_{3}^{-}$in the zone of carbonate reduction will be ignored.

The equations developed by Claypool (1974) and used by Claypool and Kaplan (1974) for the interpretation of $\delta^{13} \mathrm{C}$ of $\mathrm{HCO}_{3}^{-}$and $\mathrm{CH}_{4}$ in marine sediments are "closedsystem" treatments in the sense that only the effects of outputs $\left(\mathrm{CH}_{4}\right.$ production, carbonate precipitation) on the residual dissolved $\mathrm{HCO}_{3}^{-}$, the cumulative $\mathrm{CH}_{4}$, and authigenic carbonate were considered. Commonly, organic-matter decomposition, with consequent production of isotopically light $\mathrm{CO}_{2}$, occurs simultaneously with $\mathrm{CH}_{4}$ formation. Therefore, both inputs and outputs of $\mathrm{CO}_{2}$ must be considered for proper interpreta- tion of $\delta^{13} \mathrm{C}_{\text {of }} \mathrm{HCO}_{3}^{-}, \mathrm{CH}_{4}$, and authigenic carbonates forming in marine sediments. Equations that treat the changes in concentration and $\delta^{13} \mathrm{C}$ of dissolved $\mathrm{CO}_{2}$ as a function of input-output rates and extent of reaction progress have been presented by Wigley et al. (1978), and are adapted here for interpretation of Hole 533 results.

The concentration and $\delta^{13} \mathrm{C}$ of dissolved $\mathrm{HCO}_{3}^{-}$and the $\delta^{13} \mathrm{C}$ of $\mathrm{CH}_{4}$ in sediments of Holes 533 and 533A in the zone of carbonate reduction (below the $15-\mathrm{m}$ subbottom depth) are examined in three separate depth intervals -15 to $100 \mathrm{~m}, 100$ to $200 \mathrm{~m}$, and 200 to $400 \mathrm{~m}$. Within each depth interval, concentration trends are regular and "steady-state" conditions are assumed in the sense that increasing depth of burial is considered to be equivalent to advancing time at a given sedimentary horizon with respect to extent of progress of diagenetic reactions. The parameters of the simplest Wigley et al. (1978) equations that satisfactorily duplicate the concentration of dissolved $\mathrm{HCO}_{3}^{-}$and the $\delta^{13} \mathrm{C}$ of $\mathrm{HCO}_{3}^{-}$ and $\mathrm{CH}_{4}$ in Hole 533 are summarized in Table 3.

The $\delta^{13} \mathrm{C}$ of $\mathrm{CH}_{4}$ is not given by the Wigley et al. (1978) equations, but was calculated from isotope mass balance equations. A comparison of the observed (points) and calculated (lines) $\delta^{13} \mathrm{C}$ values versus normalized $\mathrm{\Sigma CO}_{2}$ concentration $\left(m \mathrm{C} / m \mathrm{C}_{0}\right)$ is shown in Figure 5. The initial $\mathrm{HCO}_{3}^{-}$concentration $\left(m \mathrm{C}_{0}\right)$ and $\delta^{13} \mathrm{C}$ are those observed at the top of each depth interval. Input-output ratio $(\Gamma)$ is the principal unknown: other parameters are fixed by observation or reasonable assumption. Trial-and-error calculations of $\delta^{13} \mathrm{C}$ were performed using the 1-input-1-output equation and different values for $\Gamma$. These calculations were highly sensitive to small changes in the input-output ratio, and values of 0.78 and 2 duplicated the observed data within the limits of analytical uncertainty, over the depth intervals 15 to $100 \mathrm{~m}$ and 100 to $200 \mathrm{~m}$, respectively.

In these input-output situations, the input is dissolved $\mathrm{CO}_{2}$ having $\delta^{13} \mathrm{C}$ of $-23 \%$, which is derived from the anaerobic oxidation of organic matter. The

Table 3. Parameters of input-output carbon isotope and mass balance equations (Wigley et al., 1978) that satisfactorily reproduce concentration and $\delta^{13} \mathrm{C}$ of dissolved $\mathrm{CO}_{2}$, and $\delta^{13} \mathrm{C}$ of $\mathrm{CH}_{4}$ observed in pore fluids of Holes 533 and $533 \mathrm{~A}$.

\begin{tabular}{|c|c|c|c|c|c|c|c|}
\hline \multirow[b]{2}{*}{$\begin{array}{l}\text { Sub-bottom } \\
\text { depth } \\
\text { interval } \\
\text { (m) }\end{array}$} & \multicolumn{2}{|c|}{ Initial $\mathrm{HCO}_{3}^{-}$} & \multirow[b]{2}{*}{$\begin{array}{l}\text { No. of } \\
\text { inputs, } \\
\text { outputs }\end{array}$} & \multirow[b]{2}{*}{$\begin{array}{l}\text { Input-to- } \\
\text { output } \\
\text { ratio } \\
\text { (T) }\end{array}$} & \multirow{2}{*}{$\begin{array}{c}\text { Carbonate- } \\
\text { to-methane } \\
\text { output } \\
\text { ratio } \\
(\gamma)\end{array}$} & \multicolumn{2}{|c|}{$\begin{array}{c}\text { Methane output } \\
\text { (mmol kg }\end{array}$} \\
\hline & $\underset{\left(m C_{0}\right)}{\left(\mathrm{mmol} \mathrm{kg}^{-1}\right)}$ & $\begin{array}{l}\delta^{13} \mathrm{C} \\
\left.(\% /)^{2}\right) \\
(80)^{\mathrm{a}}\end{array}$ & & & & $\begin{array}{l}\text { Depth } \\
\text { interval }\end{array}$ & Cumulative \\
\hline $15-112$ & 26 & -30 & 1,1 & 0.78 & 0 & 17 & 17 \\
\hline $112-200$ & 23 & 5.5 & 1,1 & 2 & 0 & 17 & 34 \\
\hline $200-400$ & 40 & 10.4 & 0.1 & 0 & 0 & 0 & 34 \\
\hline $200-400$ & 40 & 10.4 & 1.2 & 0.98 & 1.2 & 18 & 52 \\
\hline
\end{tabular}

Note: The Wigley et al. (1978) equation for the 1,1 or 1,2 input, output case is:

$$
\beta R-R^{*}=\left(\beta R_{0}-R^{*}\right)\left(\frac{m C}{m C_{0}}\right)^{\{\beta \Gamma /(1+\gamma+\Gamma)\}}
$$

where,

$$
\beta=1+\frac{\epsilon_{\mathrm{ms}}}{10^{3} \mathrm{r}}
$$

(when solution-carbonate fractionation is ignored) and, $\mathrm{R}={ }^{13} \mathrm{C} /{ }^{12} \mathrm{C}, \mathrm{R}^{*}=\mathrm{R}$ of input $\mathrm{CO}_{2}, \mathrm{R}_{0}$ $=\mathrm{R}$ of $\Sigma \mathrm{CO}_{2}$ at start of reaction, $m \mathrm{C}=$ molality of $\Sigma \mathrm{CO}_{2}, m \mathrm{C}=$ molality of $\mathrm{\Sigma CO}_{2}$ at start of reaction, $\epsilon_{\mathrm{ms}}=$ additive $\mathrm{CH}_{4}-\Sigma \mathrm{CO}_{2}$ fractionation factor, $10^{3}(\alpha-1), \mathrm{T}=$ ratio of $\mathrm{CO}_{2}$ input to $\mathrm{CO}_{2}$ output, $\gamma=$ ratio of carbonate output to methane output, $\alpha=$ kinetic fractionation factor for $\mathrm{CO}_{2}$ reduction, and $\mathrm{O} / m \mathrm{C}_{0}=\mathrm{CO}_{2}$ output normalized by original $\Sigma \mathrm{CO}_{2}$ concentration. a ${ }_{8}^{13} \mathrm{C}$ 的 bicarbonate, at start of reaction, as defined by Wigley et al., 1978 . 


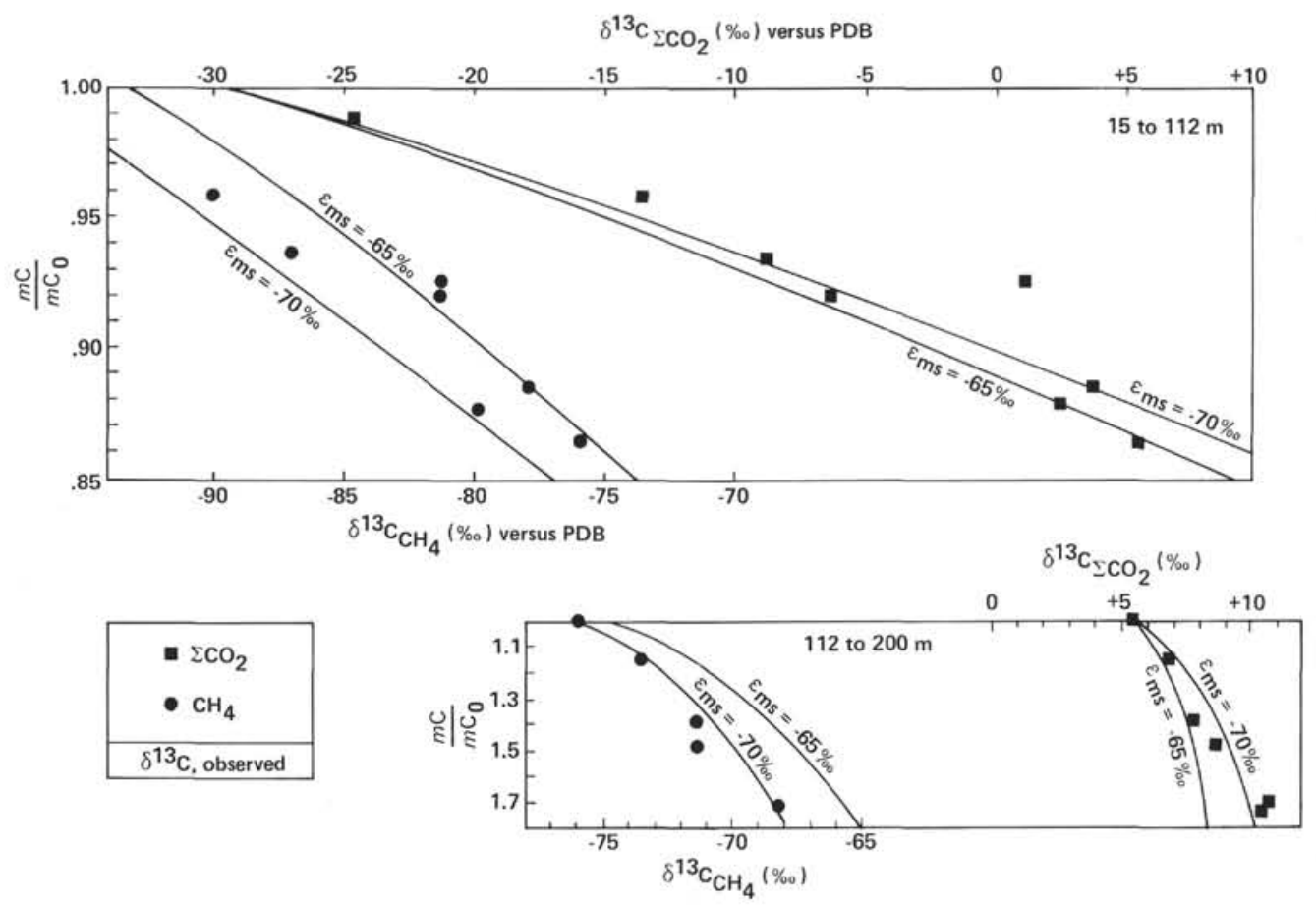

Figure 5. Observed (points) versus calculated (lines) $\delta^{13} \mathrm{C}$ values for $\mathrm{CH}_{4}$ and $\mathrm{\Sigma CO}_{2}$ as a function of extent of reaction, as indicated by change in normalized concentration of $\Sigma \mathrm{CO}_{2}\left(\mathrm{mC} / \mathrm{mC} \mathrm{C}_{0}\right)$, for the two depth intervals (15-112 $\mathrm{m}$ and $112-200 \mathrm{~m}$ ) over which $\Sigma \mathrm{CO}_{2}$ concentration changes due to methanogenesis. (Double lines for each data set are for different assumed values of the $\mathrm{CH}_{4}-\mathrm{\Sigma CO}_{2}$ additive fractionation factor $\left[\epsilon_{\mathrm{ms}}\right]$.)

output is $\mathrm{CH}_{4}$ that is depleted in ${ }^{13} \mathrm{C}$ by $70 \%$ orelative to the dissolved $\mathrm{CO}_{2}$ at the instant of formation. In order to reproduce the observed $\Sigma \mathrm{CO}_{2}$ concentration and $\delta^{13} \mathrm{C}$ trends, a major increase of input-output ratio from 0.78 to 2.0 was required at about $100 \mathrm{~m}$. That is, the rate of $\mathrm{CO}_{2}$ production was less than $80 \%$ of the rate of $\mathrm{CH}_{4}$ production over the interval from 15 to $100 \mathrm{~m}$. In contrast, the rate of $\mathrm{CO}_{2}$ production was twice that of $\mathrm{CH}_{4}$ production in the depth interval from 100 to $200 \mathrm{~m}$.

Below an unconformity at the Pliocene/Pleistocene boundary $(150 \mathrm{~m})$ sediment accumulated more rapidly and contains more organic carbon. This transition to relatively organic-rich sediment indicates a significant departure from steady-state sediment accumulation and diagenesis. A major increase in alkalinity is observed below the unconformity, and a similarly abrupt alkalinity decrease occurs over the depth interval 210 to $250 \mathrm{~m}$. The two unusually high alkalinity observations at 193 and $218 \mathrm{~m}$ (equivalent to $\mathrm{HCO}_{3}^{-}$concentration of 66 and $69 \mathrm{mmol} \mathrm{kg-1}$, respectively) were not considered for purposes of the calculations summarized in Table 3 and Figure 5. Initial trials showed that increase in both concentration and $\delta^{13} \mathrm{C}$ of $\mathrm{HCO}_{3}^{-}$could not be maintained for the 1,1 example (Table 3 ) if the input-output ratio was raised above 2.14 while the other parameters of Table 3 were kept constant. If these high alkalinity values are real, then input of isotopically heavier $\mathrm{HCO}_{3}^{-}$ is required, possibly from $\mathrm{CO}_{2}$ derived from organicmatter decarboxylation and neutralized by dissolution of biogenic carbonate. For purposes of simplifying the calculations, and in accordance with the steady-state as- sumption, the less extreme fluctuations shown by the $\Sigma \mathrm{CO}_{2}$ curve have been used, even though it was previously argued on other grounds that the alkalinity is a better measurement of the in situ $\mathrm{HCO}_{3}^{-}$concentration.

The overall trend of both the inferred $\mathrm{HCO}_{3}^{-}$concentration and the $\delta^{13} \mathrm{C}$ shows a slight decrease between 200 and $400 \mathrm{~m}$. The 1,1 example (Table 3 ) will not duplicate this change if the input $\delta^{13} \mathrm{C}$ of $-23 \%$ and the output fractionation of $-70 \%$ are maintained. Either the 0,1 example (Table 3 ) with carbonate precipitation being the only output, or the 1,2 example (Table 3 ) with formation of more authigenic carbonate than methane, will duplicate the observed small decrease in both $\mathrm{HCO}_{3}^{-}$concentration and $\delta^{13} \mathrm{C}$.

If the apparent small decreases in $\mathrm{HCO}_{3}^{-}$concentration and $\delta^{13} \mathrm{C}$ are real effects of dynamic diagenetic processes, precipitation of significant amounts of authigenic carbonate at depths greater than $200 \mathrm{~m}$ is implied. Drilling at Site 533 was terminated at $400 \mathrm{~m}$ to avoid approaching the theoretical depth of gas-hydrate instability. The presence of significant occurrences of authigenic carbonates (nodules, layers) was not noted in the initial hole summaries. This result is in contrast to the drilling on Leg 11, Holes 102, 103, and 104 on the Blake Outer Ridge about $50 \mathrm{~km}$ southeast of Hole 533, where abundant ankerite-siderite precipitation was noted (Lancelot et al., 1972). These Leg 11 carbonates were best developed at depths of 550 to $600 \mathrm{~m}$, so it may be that similar carbonate layers would have been found if drilling had been continued in Hole 533. In any case, the fitting of input-output Rayleigh equations to the data of 
Hole 533 suggests that authigenic carbonate precipitation is associated with (or follows) methane formation. This suggestion is consistent with past observation of the sediments in this region. Sampling and isotopic analysis of such authigenic carbonates would be an interesting test of the calculations described above.

Given the input-output ratios calculated from the Wigley et al. (1978) Rayleigh equations and the observed changes in concentration, the $\mathrm{CH}_{4}$ output can be estimated. The total output as a fraction of initial total dissolved carbonate is related to the normalized concentration by

$$
m \mathrm{C}_{0}=\left\{1-\left(m \mathrm{C} / m \mathrm{C}_{0}\right)\right\}\{1 /(1-\Gamma)\}
$$

according to the notation of Wigley et al. (1978), as explained in Table 3. The best fit of Hole 533 data over the depth interval from 15 to $100 \mathrm{~m}$ using the 1-input-1-output equation indicates a total $\mathrm{CH}_{4}$ output of about 17 $\mathrm{mmol} \mathrm{kg}-1$. For the depth interval from 100 to $200 \mathrm{~m}$, an additional $17 \mathrm{mmol} \mathrm{kg}^{-1}$ would be produced to give a total cumulative $\mathrm{CH}_{4}$ output of about $34 \mathrm{mmol} \mathrm{kg}-1$ at $200 \mathrm{~m}$. The concentration and $\delta^{13} \mathrm{C}$ changes between 200 and $400 \mathrm{~m}$ are so small that calculations by this technique are relatively insensitive, yielding $\mathrm{CH}_{4}$ outputs over this depth interval in the range of 0 to $20 \mathrm{mmol}$ $\mathrm{kg}^{-1}$, depending on the equations and parameters used to fit the data. These calculations suggest total cumulative methane output in the range of 35 to $55 \mathrm{mmol} \mathrm{kg}-1$ in the pore water of Blake Outer Ridge sediments at a depth of $400 \mathrm{~m}$. Methane concentrations of about 175 to $200 \mathrm{mmol} \mathrm{kg}^{-1}$ are believed to be required to saturate pore waters of marine sediments under pressures of a 3.5 to $4 \mathrm{~km}$ water column (Rice and Claypool, 1981, fig. 6). Only methane in excess of saturation is available for gas-hydrate formation. Accordingly, these calculations suggest that methane is not present in sufficient quantities to stabilize methane hydrate in Blake Outer Ridge sediments. However, it is a fact that gas hydrate was recovered from a depth of $238 \mathrm{~m}$ in Hole 533A. Moreover, geophysical evidence (Tucholke et al., 1977; Dillon et al., 1980) suggests that gas hydrates are vertically and horizontally widespread in the Blake Outer Ridge region. Therefore, either the amount of $\mathrm{CH}_{4}$ estimated by input-output calculations to have been generated is too low or the methane solubility estimates are too high, and smaller amounts of methane can stabilize gas hydrate.

Equilibrium considerations can also be used to estimate concentration of $\mathrm{CH}_{4}$ in Holes 533 and 533A sediments in conjunction with the observed $\mathrm{CO}_{2}-\mathrm{CH}_{4}$ ratio in the gas phase. The measured alkalinity, $\mathrm{pH}$, and equilibrium constants (Stumm and Morgan, 1981, table 4.8, p. 205) for the carbonate system permit estimation of in situ concentration of total dissolved carbonate present as $\mathrm{CO}_{2}$ (or $\mathrm{H}_{2} \mathrm{CO}_{3}$ ) from the equation

$$
\mathrm{K}_{1}=\left(\mathrm{H}^{+}\right)\left(\mathrm{HCO}_{3}^{-}\right) /\left(\mathrm{H}_{2} \mathrm{CO}_{3}\right)=10^{-6.1}
$$

Solving this equation for $\left(\mathrm{H}_{2} \mathrm{CO}_{3}\right)$ and dividing by the observed $\mathrm{CO}_{2}-\mathrm{CH}_{4}$ ratio provides an estimate of the in situ $\mathrm{CH}_{4}$ concentration. The $\mathrm{CH}_{4}$ concentrations estimated by this type of calculation are shown in Figure 6, along with the interpreted trends in $\mathrm{pH}$ and alkalinity used for the calculation.

The $\mathrm{CH}_{4}$ concentrations calculated in this manner provide order of magnitude agreement with the estimates of methane output given by the Wigley et al. (1978) Rayleigh equations. The equilibrium dissolved $\mathrm{CO}_{2}$ concentrations (as $\mathrm{H}_{2} \mathrm{CO}_{3}$ ) and the measured $\mathrm{CO}_{2}-\mathrm{CH}_{4}$ ratios suggest in situ $\mathrm{CH}_{4}$ concentrations of from 20 to 125 $\mathrm{mmol} \mathrm{kg}{ }^{-1}$. By this method of calculation, higher calculated $\mathrm{CH}_{4}$ content is produced by lower $\mathrm{pH}$ and $\mathrm{CO}_{2}-$ $\mathrm{CH}_{4}$ ratios and higher alkalinities. Thus outgassing of $\mathrm{CO}_{2}$ from pore waters would cause this estimate to be biased on the low side. This outgassing loss would be balanced to an unknown extent by bias on the high side because $\mathrm{CO}_{2}$ is more soluble in water than $\mathrm{CH}_{4}$. Therefore, the $\mathrm{CO}_{2}-\mathrm{CH}_{4}$ ratio in gas pockets is lower than the same ratio in the total dissolved gas under in situ conditions. There are three apparent minima in the $\mathrm{CO}_{2}-\mathrm{CH}_{4}$ ratio versus depth curve shown in Figure $6 \mathrm{~A}$, at $90 \mathrm{~m}$, $180 \mathrm{~m}$, and $285 \mathrm{~m}$. The most shallow $\mathrm{CO}_{2}-\mathrm{CH}_{4}$ ratio minimum occurs in a region of higher $\mathrm{pH}$ (7.8), and results in a calculated $\mathrm{CH}_{4}$ concentration of about 62 $\mathrm{mmol} \mathrm{kg}{ }^{-1}$. The other two $\mathrm{CO}_{2}-\mathrm{CH}_{4}$ ratio minima occur at depths where measured $\mathrm{pH}$ values were approaching 7.5 and 7.3 and give rise to calculated $\mathrm{CH}_{4}$ concentrations of about 102 and $125 \mathrm{mmol} \mathrm{kg}^{-1}$. These depths of highest calculated $\mathrm{CH}_{4}$ concentration (180 and 285 m) correspond with (but are offset down by about $25 \mathrm{~m}$ from) the approximate depth intervals of greatest observed core disturbance due to high gas content as noted by shipboard personnel (Kvenvolden and Barnard, this volume).

Major uncertainties are inherent in this equilibrium method for estimating dissolved $\mathrm{CO}_{2}$ and $\mathrm{CH}_{4}$ content of sediments, but improvements could be made by use of the in situ pore-water sampler. This calculation method and the results for Holes 533 and 533A are outlined here more for purposes of indicating another approach to interpretation of the data rather than to suggest that $\mathrm{CH}_{4}$ content has been accurately estimated with the present data.

\section{Interpretation of Organic-Matter Decomposition Processes}

The changes in concentration and stable isotope ratio of anerobic respiratory metabolites $\left(\mathrm{SO}_{4}^{2-}, \mathrm{HCO}_{3}^{-}\right.$, $\mathrm{CH}_{4}$ ) have been reasonably well documented at Holes 533 and 533A. Quantitative treatment provides combinations of inputs and outputs of the respiratory metabolites at various depths in the sediments of the Blake Outer Ridge that are consistent with the observed data.

The major processes-reactions responsible for input and output of carbon to and from the dissolved $\mathrm{HCO}_{3}^{-}$ reservoir are summarized in Table 4. Anaerobic oxidation reactions must be coupled with respiration processes to maintain the flow of electrons and permit energyyielding metabolic activity (Stanier et al., 1970, p. 215). Two types of anaerobic oxidation reactions are shown in Table 4 . The first type (1a) represents the complete 


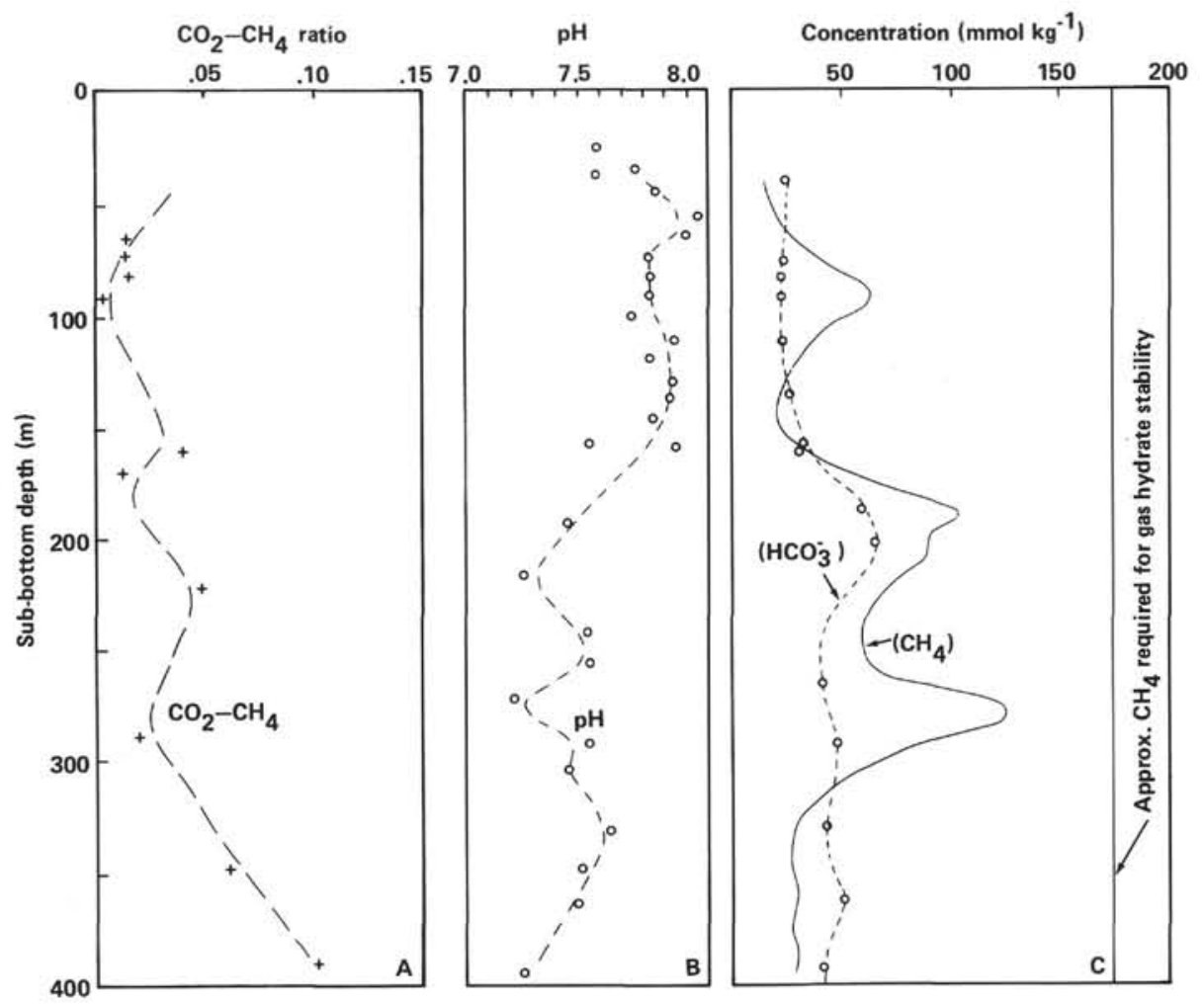

Figure 6. Interpreted trends (dashed lines) of A. $\mathrm{CO}_{2}-\mathrm{CH}_{4}$ ratio, B. pH, and C. $\mathrm{HCO}_{3}^{-}$as a function of sub-bottom depth of burial in Holes 533 and 533A. (The solid line in $\mathrm{C}$. is the calculated $\mathrm{CH}_{4}$ concentration, assuming that the $\mathrm{CO}_{2}-\mathrm{CH}_{4}$ ratio in gas pockets is directly proportional to the in situ $\mathrm{H}_{2} \mathrm{CO}_{3}-\mathrm{CH}_{4}$ ratio in the sediments. $\mathrm{H}_{2} \mathrm{CO}_{3}$ is estimated from $\mathrm{pH}$, alkalinity, and the first ionization constant for carbonic acid. Also indicated in $\mathrm{C}$. is the approximate $\mathrm{CH}_{4}$ concentration required to stabilize $\mathrm{CH}_{4}$ gas hydrate. Observed data points are plotted as crosses or open circles.)

Table 4. Early diagenetic processes affecting concentration and $\delta^{13} \mathrm{C}$ of total dissolved carbonate in pore waters of marine sediments.

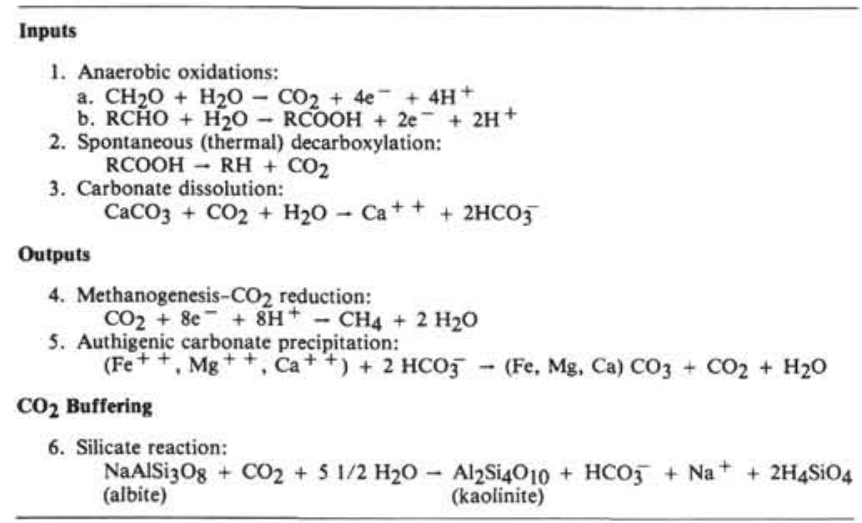

anaerobic oxidation of carbohydrate to $\mathrm{CO}_{2}$, with generation of four electrons (or $2 \mathrm{H}_{2}$ ). The other type of anaerobic oxidation (1b) illustrates electron generation without accompanying $\mathrm{CO}_{2}$ production, as in the conversion of an aldehyde to an organic acid. This type of electron- (or hydrogen-) generating reaction seems to be required because methane production via $\mathrm{CO}_{2}$ reduction usually is not accompanied by the $\mathrm{CO}_{2}$ input implied by the stoichiometry of reaction la (Table 4).
A second type of $\mathrm{CO}_{2}$ input process (2) shown in Table 4 represents nonbiological, spontaneous $\mathrm{CO}_{2}$ generation governed by first-order (time-temperature dependent) chemical kinetics. This process results in $\mathrm{CO}_{2}$ generation without production of electrons or hydrogen, and constitutes a "fermentation" reaction in the strict biochemical sense, because electron transfer occurs within the reactant organic acid molecule and results in the production of a more reduced product (schematically shown as a hydrocarbon) and a more oxidized product $\left(\mathrm{CO}_{2}\right)$. Biologically mediated direct fermentation of acetic acid is an important $\mathrm{CH}_{4}$-generating process in many nonmarine environments (Games and Hayes, 1976). Acetate fermentation is not proposed to be important for $\mathrm{CH}_{4}$ generation in anoxic marine sediments, because no mechanism is available in this process to produce the observed carbon and hydrogen (Schoell, 1980) isotope effects.

A third type of carbon input shown is carbonate dissolution. Although reaction 3 as shown in Table 4 results in the consumption of 1 mole of $\mathrm{CO}_{2}$, there is production of 2 moles of $\mathrm{HCO}_{3}^{-}$, so the result is a net input of 1 mole of $\Sigma \mathrm{CO}_{2}$ to the pore water.

The major carbon outputs from the pore-water $\mathrm{\Sigma CO}_{2}$ system are $\mathrm{CH}_{4}$ production (reaction 4), and authigenic carbonate precipitation (reaction 5). $\mathrm{CH}_{4}$ production by $\mathrm{CO}_{2}$ reduction requires a continuous supply of electrons 
from anaerobic oxidation reactions $(1 \mathrm{a}, 1 \mathrm{~b})$. Authigenic carbonate precipitation offsets the chemical effects of $\mathrm{CO}_{2}$ removal by $\mathrm{CH}_{4}$ production, and appears to be closely linked to $\mathrm{CO}_{2}$ reduction.

Also shown in Table 5 is a type of silicate reaction (6) that, in the absence of more reactive phases, can buffer the chemical effects of $\mathrm{CO}_{2}$ production and consumption, but itself produces no net change in $\mathrm{\Sigma CO}_{2}$ concentration in pore waters. When $\mathrm{CO}_{2}$ is in excess, a reaction such as the decomposition of feldspar to form clay minerals would supply the alkalinity to maintain $\mathrm{pH}$ neutrality. If electrons are in excess, the reverse reaction could occur to furnish $\mathrm{CO}_{2}$ to act as an electron acceptor, with consequent $\mathrm{CH}_{4}$ formation and production of authigenic feldspar.

In the sediments of the Blake Outer Ridge cored in Holes 533 and 533A, reactions such as 1a of Table 4 are most important in the zone of $\mathrm{SO}_{4}^{2-}$ reduction $(0-15 \mathrm{~m}$ sub-bottom), with the electrons being consumed by reduction of $\mathrm{SO}_{4}^{2-}$. Anaerobic oxidation coupled with $\mathrm{SO}_{4}^{2-}$ reduction causes the initial buildup in concentration of isotopically light $\mathrm{HCO}_{3}^{-}$. The fact that dissolved $\mathrm{HCO}_{3}^{-}$has $\delta^{13} \mathrm{C}$ as light as $-31 \%$ indicates that about $10 \%$ of the $\mathrm{HCO}_{3}^{-}$comes from oxidation of $\mathrm{CH}_{4}$. Below a sub-bottom depth of $15 \mathrm{~m}$ down to about $100 \mathrm{~m}$ in Hole 533, the decrease in $\mathrm{HCO}_{3}^{-}$indicates that $\mathrm{CO}_{2}$ is removed by $\mathrm{CH}_{4}$ production at a faster rate than $\mathrm{CO}_{2}$ is produced by anaerobic oxidation of organic matter. The requirement of an electron source for $\mathrm{CO}_{2}$ reduction implies that non- $\mathrm{CO}_{2}$-generating anaerobic oxidations such as reaction $1 \mathrm{~b}$ of Table 4 are important in this depth interval.

Dissolved $\mathrm{HCO}_{3}^{-}$increases sharply over the depth interval from 100 to $200 \mathrm{~m}$ in Holes 533 and 533A. The occurrence of a second pulse of apparent $\mathrm{CO}_{2}$ production, deeper than that associated with sulfate reduction, is a common feature of rapidly accumulating deep-sea sediments cored by DSDP. Some examples are the alkalinity profiles from Holes 147 (Hammond, 1973), 174A (Waterman et al., 1973), 262 (Cook, 1974), and 467 (Gieskes et al., 1981), as well as 533 and 533A. In Holes 147 and $174 \mathrm{~A}$, the depth of the second alkalinity or $\mathrm{HCO}_{3}^{-}$maximum was predictable from the time-temperature history of the sedimentary sequence and simple first-order decarboxylation of organic matter with reasonable, experimentally verified kinetic constants (Claypool, 1974). Although similar calculations have not been made for the data from Holes 533 and 533A, lowtemperature decarboxylation, coupled with carbonate dissolution (reactions 2 and 3 of Table 4), possibly may be the major $\mathrm{CO}_{2}$-generating processes in the depth interval from 100 to $200 \mathrm{~m}$, with $\mathrm{CO}_{2}$ reduction (reaction 4) being the main $\mathrm{CO}_{2}$-removal process.

Input-output calculations for mass balance and carbon isotopic evolution of dissolved $\mathrm{CO}_{2}$ did not require carbonate precipitation as an output, except in the depth interval between 200 and $400 \mathrm{~m}$, where $\mathrm{HCO}_{3}^{-}$decreases. The small changes in $\delta^{13} \mathrm{C}$ of $\mathrm{HCO}_{3}^{-}$or $\mathrm{CH}_{4}$ over this depth interval limit the sensitivity of input-output calculations, so there is no certainty as to whether carbonate precipitation occurs after $\mathrm{CO}_{2}$ production from or- ganic-matter decomposition and $\mathrm{CH}_{4}$ production have ceased or if these processes accompany carbonate precipitation.

More detailed interpretation of the interplay of the $\mathrm{CO}_{2}$ input, output, and buffering process outlined in Table 4 is not possible on the basis of the interstitial water chemistry alone. Knowledge of the abundance and isotopic composition of authigenic carbonate as a function of depth also is required.

\section{SUMMARY AND CONCLUSIONS}

1. Aerobic respiration and $\mathrm{SO}_{4}^{2-}$ reduction are confined to the upper $15 \mathrm{~m}$ of sediment at Site 533 on the Blake Outer Ridge. The balance between sediment accumulation rate and $\mathrm{SO}_{4}^{2-}$ reduction rate is such that about $85 \%$ of the $\mathrm{SO}_{4}^{2-}$ being reduced has diffused into the sediment from overlying seawater. The remaining $15 \%$ of the $\mathrm{SO}_{4}^{2-}$ being reduced was in the pore water buried with the sediment.

2. The $\delta^{13} \mathrm{C}_{\text {of }} \mathrm{HCO}_{3}^{-}$and $\mathrm{CH}_{4}$ in the lower part of the $\mathrm{SO}_{4}^{2-}$ reduction zone and the apparent C:S stoichiometry for $\mathrm{SO}_{4}^{2-}$ reduction indicate that $\mathrm{CH}_{4}$ oxidation is occurring above the zone of $\mathrm{CH}_{4}$ generation. The main source of the $\mathrm{CH}_{4}$ being oxidized in the zone of $\mathrm{SO}_{4}^{2-}$ reduction is upward diffusion from the underlying zone of $\mathrm{CH}_{4}$ generation.

3. Below a depth of $15 \mathrm{~m}$ in the sediment of Hole 533 the effects of $\mathrm{CH}_{4}$ generation by $\mathrm{CO}_{2}$ reduction are reflected both in the formation of gas pockets in the cored sediment and in the changes in $\delta^{13} \mathrm{C}_{\text {of }} \mathrm{HCO}_{3}^{-}$and $\mathrm{CH}_{4}$. The shallowest unaltered $\mathrm{CH}_{4}$ has $\delta^{13} \mathrm{C}$ of about -95 to $-100 \%$, and is being formed from $\mathrm{CO}_{2}$ in equilibrium with dissolved $\mathrm{HCO}_{3}^{-}$that has $\delta^{13} \mathrm{C}$ of $-31 \%$. With increasing depth of burial over the depth interval from 15 to $100 \mathrm{~m}$ in Hole 533 , the $\delta^{13} \mathrm{C}$ of coexisting $\mathrm{CH}_{4}$ and $\mathrm{HCO}_{3}^{-}$change in a manner that is consistent with the $\mathrm{CH}_{4}$ product being kinetically fractionated and not in isotopic equilibrium with the residual $\mathrm{CO}_{2}$. At greater depths of burial, the exact relationship between the $\delta^{13} \mathrm{C}$ of $\mathrm{CH}_{4}$ and $\mathrm{HCO}_{3}^{-}$is obscured by effects of nonsteadystate diagenesis and multiple carbon inputs.

4. When the changes with depth in $\delta^{13} \mathrm{C}$ and concentration of $\mathrm{HCO}_{3}^{-}$are duplicated by input-output mass balance equations (Wigley et al., 1978), cumulative $\mathrm{CH}_{4}$ production of only 35 to $55 \mathrm{mmol} \mathrm{kg} \mathrm{kg}^{-1}$ is required to produce the observed changes. In addition, in situ dissolved $\mathrm{CO}_{2}\left(\right.$ as $\left.\mathrm{H}_{2} \mathrm{CO}_{3}\right)$ can be estimated from alkalinity, $\mathrm{pH}$, and the first ionization constant for carbonic acid. If the in situ dissolved $\mathrm{CO}_{2}-\mathrm{CH}_{4}$ ratio is proportional to the observed $\mathrm{CO}_{2}-\mathrm{CH}_{4}$ ratio in gas pockets, then the calculated dissolved $\mathrm{CO}_{2}$ concentrations imply $\mathrm{CH}_{4}$ concentrations in the range of 20 to $125 \mathrm{mmol}$ $\mathrm{kg}^{-1}$. These independent estimates suggest that $\mathrm{CH}_{4}$ concentration is insufficient to saturate the pore water and stabilize $\mathrm{CH}_{4}$ hydrate. Gas hydrates are observed in Blake Outer Ridge sediments, however. This fact means that either the calculations are invalid, or some other $\mathrm{CH}_{4}$ generating process is operating, or that $\mathrm{CH}_{4}$ is not uniformly dispersed through the sediment but is somehow concentrated in discrete zones of high $\mathrm{CH}_{4}$ content. 


\section{ACKNOWLEDGMENTS}

We thank Keith Kvenvolden for assistance in obtaining the samples and for reviewing the manuscript, as did Donald Gautier. Dorothy Malone typed the manuscript, and Tom Kostick prepared the illustrations.

\section{REFERENCES}

Berner, R. A., 1981. A new geochemical classification of sedimentary environments. J. Sed. Petrol., 51:359-366.

Cappenberg, Th. E., 1972. Ecological observations on heterotrophic methane oxidizing and sulfate reducing bacteria in a pond. Hydrobiologica, 40:471-474.

Claypool, G. E., 1974. Anoxic diagenesis and bacterial methane production in deep sea sediments [Ph.D. dissert.]. University of California at Los Angeles.

Claypool, G. E., and Kaplan, I. R., 1974. The origin and distribution of methane in marine sediments. In Kaplan, I. R. (Ed.), Natural Gases in Marine Sediments: New York (Plenum), pp. 94-129.

Claypool, G. E., Presley, B. J., and Kaplan, I. R., 1973. Gas analysis of sediment samples from Legs 10,11, 13, 14, 15, 18 and 19. In Creager, J. S., Scholl, D. W., et al., Init. Repts. DSDP, 19: Washington (U.S. Govt. Printing Office), 879-884.

Claypool, G. E., Threlkeld, C. N., and Magoon, L. B., 1980. Biogenic and thermogenic origins of natural gas in Cook Inlet Basin, Alaska. Am. Assoc. Pet. Geol. Bull., 64:1131-1139.

Coleman, D. D., Risatti, J. B., and Schoell, M., 1981. Fractionation of carbon and hydrogen isotopes by methane oxidizing bacteria. Geochim. Cosmochim. Acta, 45:1022-1037.

Cook, P. J., 1974. Geochemistry and diagenesis of interstitial fluids and associated calcareous oozes, DSDP Leg 27, Timor Trough. In Veevers, J. J., Heirtzler, J. R., et al., Init. Repts. DSDP, 27: Washington (U.S. Govt. Printing Office), 463-480.

Curtis, C. D., 1977. Sedimentary geochemistry: environment and processes dominated by involvement of an aqueous phase. Phil. Trans. R. Soc. London, A286:353-71.

Dillon, W. P., Grow, J. A., and Paull, C. K., 1980. Unconventional gas hydrate seals may trap gas off southeast U.S. Oil \& Gas J., 78(1):124-130.

Games, L. M., and Hayes, J. M., 1976. On the mechanisms of $\mathrm{CO}_{2}$ and $\mathrm{CH}_{4}$ production in natural anaerobic environments. In Nriagu, J. O. (Ed.), Proc. 2nd Int. Symp. on Environmental Biogeochemistry: Ann Arbor (Science Press), pp. 51-73.

Gealy, E. L., and Dubois, R., 1971. Shipboard geochemical analysis, Leg 7, Glomar Challenger. In Winterer, E. L., Riedel, W. R., et al., 1971. Init. Repts. DSDP, 7, Pt. 2: Washington (U.S. Govt. Printing Office), 863-870.

Gieskes, J. M., Nevsky, B., and Chain, A., 1981. Interstitial water studies, Leg 63. In Yeats, R. S., Haq, B. U., et al., Init. Repts. DSDP, 63: Washington (U.S. Govt. Printing Office), 623-629.

Hammond, D. E., 1973. Interstitial water studies, Leg 15, a comparison of the major element and carbonate chemistry data from Sites 147, 148, and 149. In Heezen, B. C., MacGregor, I. D., et al., Init Repts. DSDP, 20: Washington (U.S. Govt. Printing Office), 831-850.

Holt, B. D., and Engelkemeir, A. G., 1970. Thermal decomposition of barium sulfate to sulfur dioxide for mass spectrometer analysis. Anal. Chem., 42:1451-1453.

Irwin, H., Coleman, M., and Curtis, C., 1977. Isotopic evidence for the source of diagenetic carbonate during burial of organic-rich sediments. Nature, 269:209-313.

Jannasch, H. W., 1975. Methane oxidation in Lake Kivu (central Africa). Limnol. Oceanogr., 20:860-864.

Kvenvolden, K. A., and Barnard, L. A., in press. Hydrates of natural gas in continental margins. In Watkins, J., et al., Proc. Hedberg. Conf., Am. Assoc. Pet. Geol. Mem. 34.

Lancelot, Y., 1971. Carbonate diagenesis in the gas-rich Tertiary sediments from the Atlantic North American Basin. 8th Int. Sedimentol. Cong., Heidelberg. (Abstract)
Lancelot, Y., Hathaway, J. C., and Hollister, C. D., 1972. Lithology of sediments from the western North Atlantic, Leg 11, Deep Sea Drilling Project. In Hollister, C. D., Ewing, J. I., et al., Init. Repts. DSDP, 11: Washington (U.S. Govt. Printing Office), 901-950.

Lawrence, J. R., 1973. Interstitial water studies, Leg 15, stable oxygen and carbon isotope variations in water, carbonates, and silicates from the Venezuela basin (Site 149) and the Ares Rise (Site 148). In Heezen, B. C., MacGregor, I. D., et al., Init. Repts. DSDP, 20: Washington (U.S. Govt. Printing Office), 891-900.

Lebedev, V. S., Ovsyannikov, W. M., Mogilevski, G. A., and Bogdanov, V. M., 1969. Fractionierium der Kohlenstoffisotope durch mikrobiologishe Prozesse in der biochemischen zone. Angew. Geol., 12:621-624.

Manheim, F. T., 1966. A hydraulic squeezer for obtaining interstitial water from consolidated and unconsolidated sediments. U.S. Geol. Surv. Prof. Pap. 550-C, pp. 256-261.

Postgate, J. R., 1965. Recent advances in the study of the sulfate-reducing bacteria. Bacteriol. Rev., 29:425.

Presley, B. J., 1971. Techniques for analyzing interstitial water samples. Part I: determination of selected minor and major inorganic constituents. In Winterer, E. L., Riedel, W. R., et al., Init. Repts. DSDP, 7, Pt. 2: Washington (U.S. Govt. Printing Office), 1756.

Presley, B. J., and Claypool, G. E., 1971. Techniques for analyzing interstitial water samples. Part II: determination of total carbonate and carbon isotope ratios. In Winterer, E. L., Riedel, W. R., et al., Init. Repts. DSDP, 7, Pt. 2: Washington (U.S. Govt. Printing Office), 1756-1757.

Rice, D. D., and Claypool, G. E., 1981. Generation, accumulation, and resource potential of biogenic gas. Am. Assoc. Pet. Geol. Bull., 65:5-25.

Rosenfield, W. D., and Silverman, S. R., 1959. Carbon isotope fractionation in bacterial production of methane. Science, 130:1658.

Sakai, H., 1957. Fractionation of sulfur isotopes in nature. Geochim. Cosmochim. Acta, 12:150-169.

Schoell, M., 1980. The hydrogen and carbon isotopic composition of methane from natural gases of various origins. Geochim. Cosmochim. Acta, 44:649-661.

Shipley, T. H., Houston, M. H., Buffler, R. T., Shaub, F. J., McMillan, K. J., Ladd, J. W., and Worzel, J. L., 1979. Seismic evidence for widespread possible gas hydrate horizons on continental slopes and rises. Am. Assoc. Pet. Geol. Bull., 63:2204-2213.

Sorokin, Y. I., 1957. Ability of sulfate-reducing bacteria to utilize methane for reduction of sulfates to hydrogen sulfide. Dokl. Akad. Nauk SSSR, 115:816-818.

Stanier, R. Y., Doudoroff, M., and Adelberg, E. A., 1970. The Microbial World: Englewood Cliffs, New Jersey (Prentice-Hall, Inc.).

Stoll, R. D., Ewing, J., and Bryan, G. M., 1971. Anomalous wave velocities in sediments containing gas hydrates. J. Geophys. Res., 76:2090.

Stumm, W., and Morgan, J. J., 1981. Aquatic Chemistry, (2nd ed.): New York (Wiley).

Tucholke, B. E., Bryan, G. M., and Ewing, J. I., 1977. Gas hydrate horizons detected in seismic-profiler data from the western North Atlantic. Am. Assoc. Pet. Geol. Bull., 61:698-707.

Tudge, A. P., and Thode, H. G., 1951. Thermodynamic properties of isotopic compounds of sulfur. Can. J. Res., B28:567-578.

Waples, D., 1981. Organic Geochemistry for Exploration Geologists: Minneapolis (Burgess Pub. Co.).

Waterman, L. S., Sayles, F. L., and Manheim, F. T., 1973. Appendix II: interstitial water studies on small core samples, Legs 16, 17, and 18. In Kulm, L. D., von Huene, R., et al., Init. Repts. DSDP, 18: Washington (U.S. Govt. Printing Office), 1001.

Wigley, T. M. L., Plummer, L. N., and Pearson, F. J., Jr., 1978. Mass transfer and carbon-isotope evolution in natural water systems. Geochim. Cosmochim. Acta, 42:1117-1140.

Date of Initial Receipt: August 16, 1982 